\title{
PLANTEAMIENTOS BASICOS Y EJES ESTRATÉGICOS DE LA LEY VASCA 2/2006, DE 30 DE JUNIO, DE SUELO Y URBANISMO
}

\author{
Iñigo Maguregui Salas \\ Director de Suelo del Departamento de Vivienda y Asuntos sociales del Gobierno Vasco \\ Es además, el artífice de la "Ley 2/2006, de Suelo y Urbanismo del País Vasco"
}

Remisión Artículo: 9-2-2007

Palabras Clave: Ley Vasca

\section{CONTEXTUALIZACIÓN EXTERNA DE LA LEY}

\section{Naturaleza jurídica del Urbanismo}

Cincuenta años después de la aprobación de la primera ley de suelo en el Estado español, la doctrina sigue discutiendo sobre el siguiente extremo: ¿Debe ser el Urbanismo considerado como una función pública o simplemente debe limitarse a regular la actividad del mercado del suelo ordenando la forma de obtención privativa por la propiedad del suelo de las plusvalías generadas por la acción urbanística?

Evidentemente no es objeto de este artículo hacer un exhaustivo análisis de los posicionamientos históricos sobre esta cuestión pero el entendimiento de determinadas opciones de los legisladores estatales y autonómicos en materia de régimen del suelo y del urbanismo sólo puede ser comprendido a la luz de la toma de posición concreta respecto a esta cuestión.

Sobre la base de un diagnóstico compartido - la carestía del suelo y de la vivienda, la lucha contra la especulación - las recetas propuestas por las posiciones más conservadoras partidarios del libre funcionamiento del mercado de suelo y vivienda - y las progresistas defensores de la función pública urbanística, de la planificación territorial y urbanística y de la intervención pública en el mercado de suelo y de vivienda - siguen siendo irreconciliables.

Aunque desde el punto de vista estrictamente económico pueda considerarse que el suelo y la vivienda son productos del mercado de bienes y servicios, sus características de bienes de primera necesidad y el hecho que su oferta y demanda tengan un carácter marcadamente local explica que el sistema urbanístico español haya intentado históricamente compatibilizar el contenido y el régimen jurídico-económico de la propiedad urbana con los objetivos públicos de asegurar que la producción de suelo urbanizado para usos residenciales y de actividad económica se ajuste a las necesidades de los ciudadanos ${ }^{1}$.

\footnotetext{
${ }^{1}$ Ya el legislador español de 1956 se refería a esta cuestión en su Exposición de Motivos:

"Si ideal en la empresa urbanística pudiera ser que todo el suelo necesario para la expansión de las poblaciones fuera de propiedad pública, mediante justa adquisición, para ofrecerlo, una vez urbanizado, a quienes deseasen edificar, la solución, sin embargo no es viable en España. Requeriría de fondos extraordinariamente cuantiosos (...)"
} 
Según los partidarios de la liberalización plena del mercado del suelo, es la limitación de la oferta de suelo urbanizable producida por las clasificaciones de suelo del planeamiento territorial y urbanístico la responsable de la subida de los precios del suelo, de modo que los propietarios de suelo legítimamente retienen los terrenos en búsqueda de la mejor renta y el mejor uso de los mismos, que les podría otorgar el mercado. Así, y consecuentemente, la plusvalía urbanística se equipara por los partidarios de esta postura como parte del "ius aedificandi" íntimamente e indisolublemente relacionado con el estatuto jurídico de la propiedad del suelo, según la legislación civil. La plusvalía urbanística corresponde a los propietarios del suelo - clase terrateniente - por lo que todo el sistema urbanístico de cesiones a favor de la Administración Pública de aprovechamiento urbanístico y de superficies de suelo urbanizado con destino a dotaciones públicas locales es, simplemente, un factor de encarecimiento del producto inmobiliario.

Por el contrario los partidarios de la intervención administrativa en el mercado del suelo oponen que la oferta, ni aun indiscriminada, de suelo bruto haya mostrado efectos de abaratamiento. Por otra parte, desde la perspectiva de construcción armónica y equilibrada de la ciudad concebida no como un puro mercado sino como lugar donde el ciudadano habita, desarrolla su vida y donde se juega su calidad de vida, el planeamiento territorial y urbanístico es un instrumento indispensable. Además, el mercado del suelo y su utilización y uso deben ser puestas por mandato constitucional al servicio del interés general más concretamente a través de su efectivo sometimiento a los derechos ciudadanos al medio ambiente, al patrimonio cultural y sobre todo al derecho a la vivienda. Dichos principios constitucionales deben funcionar como límites efectivos al libre mercado del suelo en tanto este libre mercado no permite garantizar el cumplimiento efectivo de los mismos. Desde este punto de vista, la intervención administrativa para orientar el mercado del suelo hacia estos principios no sólo es conveniente sino que es constitucionalmente exigible ${ }^{2}$.

Hoy por hoy el problema del acceso a la vivienda, en cualquier régimen de tenencia, por la carestía de la misma y su imparable dinámica alcista de precios parece justificar, en correcta interpretación, entre otros, del propio artículo $47 \mathrm{CE}^{3}$, el sometimiento de la actividad urbanística a los intereses públicos en garantía de dichos principios constitucionales.

Por ello, se convierte en urgente reclamar que la actividad urbanística no sólo supone la regulación de unas concretas condiciones del mercado inmobiliario. La importancia del "hecho urbanístico" radica más bien en que su ejercicio condiciona derechos constitucionales universales como el acceso a una vivienda digna y adecuada así como el acceso a un entorno urbano y medioambiental adecuado y sostenible, entre otros. Por todo ello, la reivindicación del Urbanismo como función pública en base al papel que deben jugar la planificación y la programación públicas urbanísticas en garantía de los citados derechos se hace indispensable.

\footnotetext{
${ }^{2}$ Esa es la orientación del reciente proyecto de ley estatal del suelo aprobado por el Consejo de Ministros el pasado mes de Julio que en su Exposición de Motivos ya se decanta por integrar el régimen del suelo en el contexto de la garantía del acceso de todos los ciudadanos a los derechos constitucionales a él asociados, apartándose así de la posición de limitar la regulación a la garantía de los derechos de los propietarios privados de suelo.

El artículo 47 de la Constitución Española reza lo siguiente: "Todos los españoles tienen derecho a disfrutar de una vivienda digna y adecuada. Los poderes públicos promoverán las condiciones necesarias y establecerán las normas pertinentes para hacer efectivo este derecho, regulando la utilización del suelo de acuerdo con el interés general para impedir la especulación. La comunidad participará en las plusvalías que genere la acción urbanística de los entes públicos."
} 


\section{La liberalización del suelo. La Ley 6/1998 de Suelo y Valoraciones}

La apuesta por la liberalización del mercado inmobiliario se plasma con bastante claridad en la actual Ley 6/1998 de Régimen del Suelo y de Valoraciones. Bajo la premisa de que el abaratamiento de los precios en el mercado del suelo llevaría al inexorable abaratamiento de la vivienda, la Exposición de Motivos ya avanza sus pretensiones de flexibilización y liberalización frente a posiciones intervencionistas de legislaciones precedentes - Ley del Suelo de 1990 y Texto Refundido de 1992 - a las que se califican de fracasadas ${ }^{4}$. Dicha Exposición de Motivos termina convirtiéndose en la abierta defensa de un corolario de críticas y propuestas de modificación que resumen a la perfección la posición liberalizadora. Entre ellas, merecen la pena destacarse las siguientes:

1. Aumento de la oferta de suelo. Las clasificaciones de suelo hechas por los planes urbanísticos como suelo urbano y como suelo no urbanizable deben ser expresamente justificadas. Especialmente sólo se puede declarar como suelo no urbanizable aquellos terrenos que incorporen objetivamente un valor expreso a proteger, haciendo desaparecer la categoría de "suelo no urbanizable de régimen común". El resto del suelo debe ser clasificado como urbanizable.

2. Preferencia de la iniciativa privada frente a la gestión pública. De hecho, la gestión pública debe fomentar la participación privada.

3. Reconocimiento de derechos a favor de los propietarios de suelo urbano y urbanizable hasta un mínimo del $90 \%$ de la plusvalía urbanística sin vincular la materialización del derecho al cumplimiento de deberes.

4. La acción urbanizadora es concebida como un deber de la propiedad del suelo y no como una obra pública al servicio del interés general.

5. Otorgamiento de la plusvalía derivada de la acción urbanística "a priori" a favor de la propiedad del suelo urbano y urbanizable a través de un sistema de valoraciones basado en expectativas de mercado y no en realidades.

6. Establecimiento de limitaciones jurídicas a las administraciones públicas en el ejercicio de las facultades de expropiación forzosa a través de la regulación del supuesto de reversión expropiatoria.

Es inequívoca la apuesta por la propiedad privada del suelo frente a la intervención de la administración pública. Para el correcto funcionamiento del sistema, la ley centra sus esfuerzos en amparar los derechos patrimoniales de los propietarios privados de suelo frente a la acción de las administraciones públicas. El legislador confía en que el mercado estructure por sí mismo correctamente su funcionamiento de modo que los "usos urbanísticos débiles" - como la vivienda protegida, entre ellos - no sean precisos por el abaratamiento de la vivienda derivado del aumento de la oferta de suelo y vivienda.

\footnotetext{
${ }^{4}$ La Exposición de Motivos de la actual ley 6/1998 comienza así:

"Las sucesivas reformas de nuestra legislación urbanística han ido incrementando la complejidad de este sector del ordenamiento jurídico al multiplicar, a veces innecesariamente, las intervenciones administrativas en las distintas fases de los procesos de desarrollo urbano, lo que, unido a la limitación en la oferta de suelo, ha contribuido necesariamente a demorar hasta extremos irrazonables la conclusión de las operaciones de urbanización y ulterior edificación haciendo imprevisible su coste y dificultando una adecuada programación de las actividades empresariales, con el consiguiente encarecimiento del producto final".
} 
La realidad, como todos desgraciadamente conocemos, ha sido bien distinta. El blindaje de los derechos de los propietarios privados de suelo y la obtención anticipada de la plusvalía urbanística se han consagrado en el panorama jurídico mientras los resultados prometidos por la liberalización de abaratamiento de la vivienda han sido un rotundo fracaso. Para agudizar el problema, las administraciones públicas ven su capacidad de actuación e intervención administrativas muy limitadas debido, por una parte, a las limitaciones jurídicas propuestas por la norma y, muy especialmente, debido a un sistema de valoraciones que otorga la plusvalía urbanística con carácter anticipado al cumplimiento de deberes del propietario original de los suelos. Conviene, llegados a este punto, recordar que el legislador de suelo de 1956 ya advertía de que unos de los principales peligros de hacer descansar la acción urbanística en la propiedad privada del suelo, modelo por el que se terminó apostando también en sucesivas legislaciones sobre el suelo, era la obtención privada de forma anticipada de la plusvalía urbanística sin haberse cumplido con los deberes inherentes a dicha plusvalía - la urbanización y el cumplimiento de las cesiones $-{ }^{5}$. Dicho en otras palabras, cincuenta años después de insistir en un modelo urbanístico fracasado que hace descansar prioritariamente la acción pública urbanizadora en el estatuto jurídico-civil de la propiedad de los terrenos, se hace urgente reclamar un cambio de paradigma.

Merece mención aparte el proyecto de ley de suelo aprobado recientemente en el mes de Julio por el Consejo de Ministros. Este proyecto normativo es la reacción más plausible al desolador panorama dibujado líneas más arriba. En él, además de la configuración novedosa de un estatuto de derechos y deberes de los ciudadanos frente a la acción urbanística de los entes públicos, se devuelven a la administración pública la iniciativa de la acción urbanística y las facultades de intervención en el mercado de suelo y vivienda. Así, se retoma la idea de la función pública urbanística. Por otra parte, y en lo que es más importante, se reconfigura el sistema de valoraciones de suelo en base a realidades y no expectativas especulativas, tal como exige nuestra Constitución en el ya citado artículo 47.

\section{La función pública urbanística en la Ley 2/2006 de Suelo y Urbanismo de la CAPV}

\footnotetext{
5 "El régimen jurídico de suelo encaminado a asegurar su utilización conforme a la función social que tiene la propiedad resulta el cometido más delicado y más difícil que ha de afrontar la ordenación urbanística. Y se impone, sin embargo efectuarlo precisamente porque si la propiedad privada ha de ser reconocida y amparada por el Poder Público, también debe armonizarse el ejercicio de sus facultades con los intereses de la colectividad. Diversos problemas relativos al suelo requieren solución y entre ellos los siguientes:
}

a) La retención de terrenos por los propietarios que no urbanizan ni edifican ni acceden a enajenar sus terrenos para urbanizar y construir a precios de justa estimación. En la evaluación del suelo que circunda el núcleo urbano prepondera, en efecto, la tendencia de hacer actuar expectativas de uso o rentas futuras, que se incorporan así, como valores adicionales al valor actual del fundo; se computa indebidamente la plusvalía, que en su momento será el resultado principal de la inversión urbanizadora, sin tener en cuenta que en rigor [la plusvalía] debe estar ausente del cálculo, puesto que cuando efectivamente llegue a producirse como consecuencia de las obras en proyecto, ha de revertir en gran parte a la comunidad, previa aplicación del sistema fiscal adecuado. Lo cierto es, sin embargo, que suelen pretenderse precios de especulación en lugar de precios reales y en tanto se consiguen o no se hace imposible o se demora la movilización de la propiedad territorial, es decir, se impide la parcelación, venta y edificación de los solares resultantes y la saturación del mercado con ofertas de terrenos a precios razonables. El beneficio que puede obtenerse de transformar un suelo rústico en solar es perfectamente lícito siempre que sea el propietario el que haya costeado la urbanización determinante de aquella mejora y subsiguiente incremento de valor. Pero, en cambio, la caprichosa elevación del precio cuando todavía no se ha urbanizado ni desembolsado por los propietarios el coste de las obras correspondientes implica usurpación de algo no perteneciente al dueño y que repercute en perjuicio de toda la comunidad.

(...)" 
El legislador vasco concede al Urbanismo la naturaleza de función pública. Así, en su artículo 2.1 dispone:

"El urbanismo es una función pública que tiene por objeto la ordenación, programación, dirección, supervisión, control y, en su caso, ejecución de:

a) La utilización o uso del suelo

b) La transformación urbanística del suelo mediante la ejecución de la ordenación urbanística que se materializa en su urbanización y edificación

c) La construcción y la edificación

d) El uso, la conservación y la rehabilitación de construcciones, instalaciones y edificaciones"

Esta idea se desarrolla en el párrafo tercero del mismo artículo desglosando las potestades administrativas asociadas a la "función pública urbanística" entre las que se citan, la concreción del régimen urbanístico del suelo, la ordenación urbanística, la ejecución de dicha ordenación, la regulación e intervención en el mercado del suelo y la vivienda, la intervención en las facultades dominicales relativas al uso del suelo y de la edificación, la protección de la legalidad urbanística y la garantía de la participación ciudadana. Cada una de estas potestades se corresponde con los Títulos y Secciones siguientes en los que subdivide el texto legal.

Finalmente el citado artículo segundo, en su párrafo cuarto, establece que los principios generales del urbanismo, que son desarrollados en los artículos siguientes, orientan el ejercicio de las potestades administrativas inherentes a la función pública urbanística ${ }^{6}$. Nuevamente, a través de estos principios, aparece la idea de que la necesidad de proteger dichos intereses justifica la configuración del urbanismo como el desarrollo de una auténtica función pública.

Sin perjuicio que más adelante se vuelva más detalladamente sobre el particular, la función pública urbanística, según la propia Exposición de Motivos, es la base sobre la que se articulan los siguientes objetivos de la norma ${ }^{7}$ :

1. Recuperación de la iniciativa en manos de las administraciones públicas en las actuaciones urbanísticas reforzando los instrumentos de intervención y de control y supervisión de la actividad privada. Entre dichos instrumentos se destacan por el propio legislador los programas de actuación urbanizadora y los programas de edificación forzosa.

2. Interdicción de la especulación inmobiliaria buscando a la par la flexibilización en la gestión de la documentación de ordenación urbanística y la efectividad en la puesta en práctica de los instrumentos de gestión y ejecución.

\footnotetext{
${ }^{6}$ Entre estos principios destacamos, por novedosos en el panorama autonómico, los siguientes: El desarrollo sostenible, la participación ciudadana y la subordinación de la actividad urbanística al interés público y que se concreta en el acceso a una vivienda, a un empleo digno, a un medioambiente urbano y natural adecuado, al acceso al patrimonio cultural y en el derecho de la comunidad a la participación en las plusvalías urbanísticas - todos ellos derechos reconocidos constitucionalmente -. En forma de deberes para las administraciones públicas, el interés público se concreta en la responsabilidad de supervisar el cumplimiento de las determinaciones y de los plazos de la planificación urbanística y evitar la especulación a través de la intervención administrativa en el mercado de suelo y resto de bienes inmuebles.

${ }^{7}$ La redacción concreta se puede encontrar en el apartado tercero de la Exposición de Motivos de la Ley vasca 2/2006 de Suelo y Urbanismo (BOPV 138).
} 
3. Impulso a las políticas públicas en materia de vivienda protegida y de suelo para actividades económicas de interés público para lo que se actualizan y se refuerzan los mecanismos de intervención administrativa en el mercado del suelo y de la vivienda en manos de las administraciones públicas.

4. Orientación de la práctica urbanística hacia los principios del interés público y, específicamente, de desarrollo sostenible aplicado a modelos urbanos a través de la consideración de su relación con el medio ambiente natural y la prevalencia de la preservación y regeneración del patrimonio urbanizado y edificado, especialmente en los bienes integrantes del patrimonio cultural, sobre los nuevos desarrollos.

5. Fomento de la participación ciudadana a través de instrumentos novedosos de existencia obligatoria en determinados municipios y refuerzo de los sistemas de información urbanísticos.

A lo largo del artículo y de la mano de estos ejes estratégicos se irán abordando las principales novedades introducidas por la reciente legislación urbanística vasca. Así mismo, estos objetivos son los que sirven de base y orientación para el correcto entendimiento e interpretación de la norma aprobada.

Para finalizar este apartado debemos apostillar que una reconfiguración de la actividad urbanística en aras a alcanzar la consecución de los objetivos señalados requiere necesariamente reflexión y alteraciones en relación a la concreta distribución competencial de la actividad urbanística. El nuevo escenario competencial que se dibuja en la ley se articula sobre la base de superación de un escenario de competencias exclusivas a un escenario de corresponsabilidad y concertación interadministrativa y ciudadana. 


\section{CONTEXTUALIZACIÓN INTERNA DE LA LEY}

\section{$\underline{\text { Introducción }}$}

Siempre se ha pensado que el País Vasco carecía de un modelo urbanístico propio al no disponer hasta fechas recientes de una ley urbanística autonómica. Aunque ello tiene parte de verdad, la afirmación anterior merece la pena ser matizada.

La singularidad territorial del País Vasco debido, por una parte, a la compleja orografía que se impone en gran parte de su territorio, a la escasez superficial de su extensión, al complejo panorama político-institucional y a la práctica ausencia de suelos aptos para intervenciones estratégicas de escala supramunicipal ha terminado derivando en un modelo de ordenación en que las escalas local y territorial muchas veces se han terminado confundiendo.

De este modo, la disposición desde 1997 de Directrices de Ordenación Territorial ya presuponía la existencia de un modelo de ordenación y de intervención sobre el territorio suficientemente amplio como para orientar y condicionar las determinaciones de los planes urbanísticos.

Así, el legislador vasco durante bastantes años se limitó en materia urbanística a regular determinados aspectos concretos, algunos de forma urgente, remitiéndose por lo demás a la legislación general que aplicaba en el Estado. Conviene resaltar aquellas materias de conexión con la materia urbanística a las que el legislador vasco sí atendió con anterioridad a la actual ley 2/2006 por entender que requerían una respuesta más específica en el País Vasco ${ }^{8}$. Nos referimos concretamente a la materia de valoraciones de suelo (1989), ordenación territorial (1990), políticas de vivienda pública (1994), agilización de tramitación urbanística (1994), protección del medio ambiente (1998), clasificación de suelo como suelo no urbanizable y como suelo para vivienda protegida (1998), aspectos competenciales en materia de urbanismo (1998), introducción de plazos en la formulación de planes urbanísticos y en su ejecución (1998), regulación de la participación de la comunidad en las plusvalías urbanísticas (1998) y patrimonios públicos de suelo (1998).

Como se observará, las leyes autonómicas vascas posteriores al Texto Refundido de Régimen de Suelo y Ordenación Urbana (1992) desarrollan aspectos que también han sido capitales y coinciden con los objetivos expuestos por el legislador vasco en la ley 2/2006 y descritos en el apartado anterior. Ello, evidentemente, aunque no permite hablar de la existencia de un concreto modelo urbanístico vasco tampoco permite defender una ausencia total del mismo.

La Sentencia del Tribunal Constitucional 61/1997, al declarar inconstitucional toda la normativa estatal de referencia urbanística supletoria, dio al traste con esta práctica de remisiones legislativas encontrándose, a partir de ese momento, los operadores urbanísticos vascos remitidos a la legislación en materia de suelo y urbanismo preconstitucional - Texto Refundido de 1976 -. Ello convirtió en urgente la disposición de una legislación urbanística vasca integral

\footnotetext{
${ }^{8}$ Las referencias de las leyes mencionadas son las siguientes: Ley 9/1989, de 17 de noviembre, de Valoración de Suelo de la CAPV, Ley 4/1990, de 31 de Mayo, de Ordenación del Territorio del País Vasco, Ley 17/1994, de 30 de junio, de Medidas Urgentes en materia de Vivienda y de Tramitación de instrumentos de planeamiento y gestión urbanísticas, Ley 3/1998, de 27 de Febrero, General del Protección del Medio Ambiente, Ley 5/1998, de 6 de marzo, de medidas urgentes en materia de régimen de suelo y ordenación urbana, Ley 11/1998, de 20 de abril, de modificación de la ley por la que se determina la participación de la comunidad en las plusvalías generadas por la acción urbanística, Ley 20/1998, de 29 de junio, de Patrimonios Públicos de Suelo.
} 
e integrada, necesidad a la que ha venido a dar respuesta la reciente Ley 2/2006 de Suelo y Urbanismo.

A continuación, daremos un breve repaso a aquellas normas autónomas vascas que, por su carácter, en mayor medida han contribuido a contextualizar las estrategias y objetivos de la ley urbanística vasca.

Las Directrices de Ordenación Territorial. Decreto 28/1997, de 11 de Febrero.

A continuación, se presenta un cuadro explicativo a modo de resumen de las ideas - fuerza que, a modo de estrategias de intervención territorial, fueron aprobadas por el Gobierno Vasco.

\section{Modelo territorial de las Directrices de Ordenación del Territorio \\ "Territorio como herencia y como proyecto" \\ Ordenación Territorial y Urbanismo como función pública}

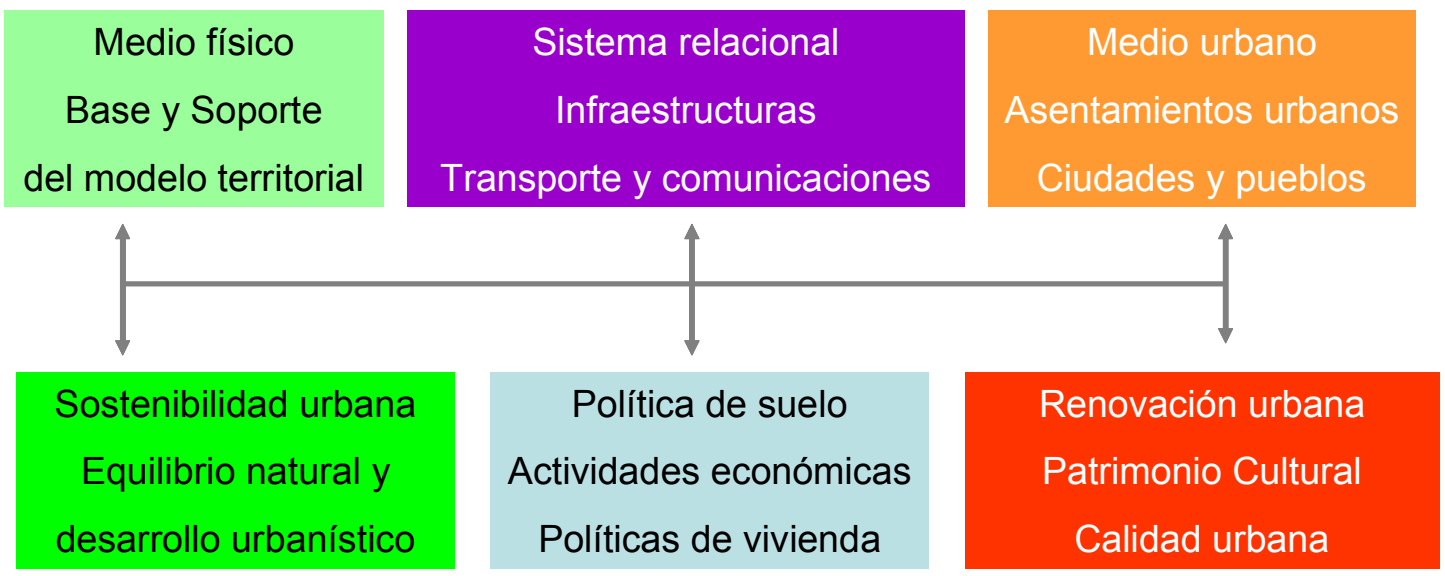

\section{Distribución competencial de planeamiento y de estrategias entre}

las escalas Local y Territorial compatible con participación ciudadana

Flexibilidad, efectividad, intervención, concertación público - privada

Fuente: Elaboración propia

Las Directrices de Ordenación Territorial tuvieron como principal objetivo compatibilizar la preservación del medio físico ("territorio como herencia") con su necesaria coexistencia con los otros dos elementos transformadores de dicho medio natural ("territorio como proyecto"); nos referimos al sistema de asentamientos urbanos, por una parte, y la constitución de una red relacional de transporte y comunicaciones, por otra.

Consecuencia lógica de la búsqueda de esa coexistencia - nunca pacífica, por otra parte - se determinaron una serie de estrategias y se configuraron una serie de límites y normas de aplicación directa. Así, destacaríamos el tratamiento de protección y la categorización del suelo no urbanizable y del resto de los recursos naturales, la configuración de áreas territoriales homogéneas de influencia, el establecimiento de los límites de crecimiento poblacional de pueblos y ciudades, la necesidad de articulación de una estrategia común de colonización transformadora de nuevos suelos con usos mixtos residenciales y de actividades económicas y 
el desarrollo de políticas activas en materia de regeneración y rehabilitación urbana con especial atención tanto en núcleos históricos - urbanos y rurales - como en áreas social y ambientalmente degradadas, etc.

Estas estrategias se articulan en torno a dos figuras de planeamiento de desarrollo de la ordenación territorial como son los Planes Territoriales Parciales - que tienen por objeto el tratamiento integral de un área homogénea también llamada área funcional y cuyas determinaciones son vinculantes a los planes urbanísticos - y los Planes Territoriales Sectoriales - que tienen por objeto el tratamiento sectorial de toda la Comunidad Autónoma desde la perspectiva territorial y cuyas determinaciones, salvo excepciones, sirven de recomendaciones a los planes urbanísticos -. Así, por ejemplo, la Ley 4/1990, de Ordenación del Territorio, encomendaba a los Planes Territoriales Parciales la cuantificación residencial de vivienda protegida que debía ser calificada por cada municipio en sus respectivos planeamientos urbanísticos.

Prosiguiendo el esquema antes expuesto, el legislador vasco a la hora de abordar una legislación urbanística debía fomentar y facilitar las estrategias territoriales siguientes:

a) Fomento de la sostenibilidad. Búsqueda de un equilibrio entre el espacio natural y los necesarios desarrollos urbanísticos.

b) Impulso a las políticas públicas de desarrollo de suelo tanto en materia de vivienda protegida como de implantación de actividades económicas, todo ello actualizando los instrumentos propios de la intervención administrativa.

c) Dotar a las administraciones urbanísticas de más y mejores herramientas para intervenir en el territorio en la búsqueda de mayor calidad urbana y mejor aprovechamiento del patrimonio urbanizado y edificado mediante políticas de regeneración urbana y rehabilitación.

A continuación, sin ánimo de ser exhaustivos, haremos un recorrido por aquellas leyes de índole urbanística y que disponía la Comunidad Autónoma Vasca con anterioridad a la aprobación de la Ley 2/2006 de Suelo y Urbanismo. Este repaso resulta indispensable para entender la toma de determinadas opciones legislativas, toda vez que el marco legislativo precedente influyó decisivamente en el texto que finalmente fue aprobado. Por ello, nos centraremos en la Ley 17/1994 de Medidas Urgentes relativa a la materia de vivienda y, en menor medida, a la agilización en plazos de la documentación urbanística, en la Ley 5/1998 de Medidas Urgentes, en la Ley 11/1998 relativo a la participación de la comunidad en las plusvalías urbanísticas, interesante para nuestro análisis por haber sido objeto de una sentencia de constitucionalidad en el año 2002 y finalmente, la Ley 20/1998 de Patrimonios Públicos de Suelo.

Ley $17 / 1994$, de 30 de junio, de Medidas Urgentes en materia de Vivienda y de Tramitación de los Instrumentos de Planeamiento y Gestión Urbanística ${ }^{9}$

Esta ley quizás sea una de las más comentadas y a la par polémicas de cuantas han sido promulgadas por el legislador vasco en materia urbanística. Lo cierto es que el cuerpo legislativo de la ley iba dirigido principal y fundamentalmente al problema de la vivienda, por lo que nos centraremos en el análisis de este aspecto en este apartado.

\footnotetext{
${ }^{9}$ La ley fue publicada en el Boletín Oficial del País Vasco número 145 de 1 de agosto de 1994
} 
El objeto principal de esta ley radica en que, por primera vez y de forma novedosa en la legislación comparada estatal, se imponía por ley a los planeamientos urbanísticos de los municipios de más de 7.000 habitantes la obligación de calificar suelo para la construcción de viviendas cuyo precio fuera susceptible de ser tasado por la Administración. Así, en los ámbitos de uso residencial era obligatoria la calificación de suelo necesario para materializar el $65 \%$ del aprovechamiento residencial en suelo urbanizable y el $20 \%$ en las operaciones urbanísticas de transformación en suelo urbano.

Esta novedad también puede ser interpretada como el reconocimiento oficial del fracaso de la intervención administrativa en el mercado de suelo para garantizar la presencia de los "usos urbanísticos débiles" - como la vivienda protegida -. La constitución de los patrimonios públicos de suelo - a los que se hacía referencia en la legislación de 1956 y de 1975 - no daba respuesta suficiente, por diferentes motivos en los que no podemos detenernos, a las necesidades que se detectaban en la sociedad.

Con carácter precedente, dicha encomienda de reserva de suelo para la construcción de vivienda protegida o bien se reservó a las determinaciones del propio planeamiento - extremo que fue arrumbado por la jurisprudencia al entender que el rango normativo de los planes urbanísticos no era suficiente para imponer un límite al aprovechamiento urbanístico obtenible por la propiedad privada de suelo ${ }^{10}$ - o bien se reservó a los instrumentos de ordenación territorial vía encomienda legal. Este segundo supuesto era el propio de la Comunidad Autónoma del País Vasco en el que la precedente Ley 4/1990 de Ordenación del Territorio expresamente reservaba dicha encomienda de cuantificación y obligación de calificación de suelo para vivienda protegida a los Planes Territoriales Parciales de las respectivas áreas funcionales ${ }^{11}$, aunque las Directrices de Ordenación Territorial hacían esta encomienda a favor de un Plan Territorial Sectorial.

La urgencia en la disposición de suelos calificados fue el argumento esgrimido para imponer esta obligación legal en contra de lo legislado con carácter precedente. Por ello, la opción fue imponer la obligación directamente y no esperar al desarrollo de los instrumentos de ordenación territorial y a las revisiones de los correspondientes planes urbanísticos.

Lo cierto y verdad es que la aparición de esta ley supuso un cambio importante en la forma de hacer urbanismo conocida hasta aquel momento ya que se sustituyó de forma definitiva la ordenación territorial, cuya materialización normativa era la de decreto, por la vía legal. También fue ese el principal argumento de crítica que se hizo a la citada ley desde el mundo municipal.

Más de diez años después son muy controvertidos los resultados que ha obtenido esta norma, alabada por unos y denostada por otros. Por ello se hace preciso en estos momentos, en aras a la objetividad, suministrar algunos datos que ilustren hasta qué punto dicha ley ha sido efectiva. Para ello, se suministrarán datos relativos al número de viviendas protegidas que supone el suelo ya calificado por los planes urbanísticos hoy vigentes y cómo se ha ido materializando históricamente dicha obligación a través de la estadística de viviendas protegidas iniciadas.

Según las últimas cifras arrojadas por el banco de datos territoriales del País Vasco dependiente del Departamento de Medio Ambiente y Ordenación del Territorio del Gobierno

\footnotetext{
${ }^{10}$ Para más información consultar ARZUA AGUSTíN "A propósito de la Ley 17/1994, de 30 de junio, de medidas urgentes en materia de Vivienda y de Tramitación de los Instrumentos de Planeamiento y Gestión Urbanística". Revista Vasca de Administración Pública, número 41.

${ }^{11}$ Véase el artículo 12.1 apartado f) de la Ley 4/1990, de 31 de mayo, de Ordenación del Territorio del País Vasco.
} 
Vasco ${ }^{12}$, el número de viviendas protegidas posibilitadas en los años 2004 y 2005 por la superficie de suelo calificada por el planeamiento urbanístico es el siguiente:

\begin{tabular}{|l|c|c|}
\hline & Suelo para viviendas 2004 & Suelo para viviendas 2005 \\
\hline Suelo urbano & 13.462 viviendas & 14.707 viviendas \\
\hline Suelo urbanizable & 27.328 viviendas & 31.228 viviendas \\
\hline Totales & 40.790 viviendas & 45.935 viviendas \\
\hline
\end{tabular}

Fuente: Elaboración propia a partir de datos UDALPLAN 2004 y 2005

Los datos muestran que los planes urbanísticos, cuyas cifras de calificación de suelo dan razonable respuesta a las necesidades de acceso de vivienda en la CAPV a corto y medio plazo $^{13}$, no se convierten en un problema para el desarrollo de una política activa de vivienda protegida. No obstante, las necesidades ciudadanas no son satisfechas por la simple calificación de viviendas sino que la efectividad de la ley debería medirse también en función del número de viviendas protegidas iniciadas- índice cuantitativo - y su relación con el número de viviendas totales iniciadas - peso relativo de la vivienda protegida en relación con el total de la construcción residencial -. A continuación se muestra un gráfico ilustrativo de ese extremo.

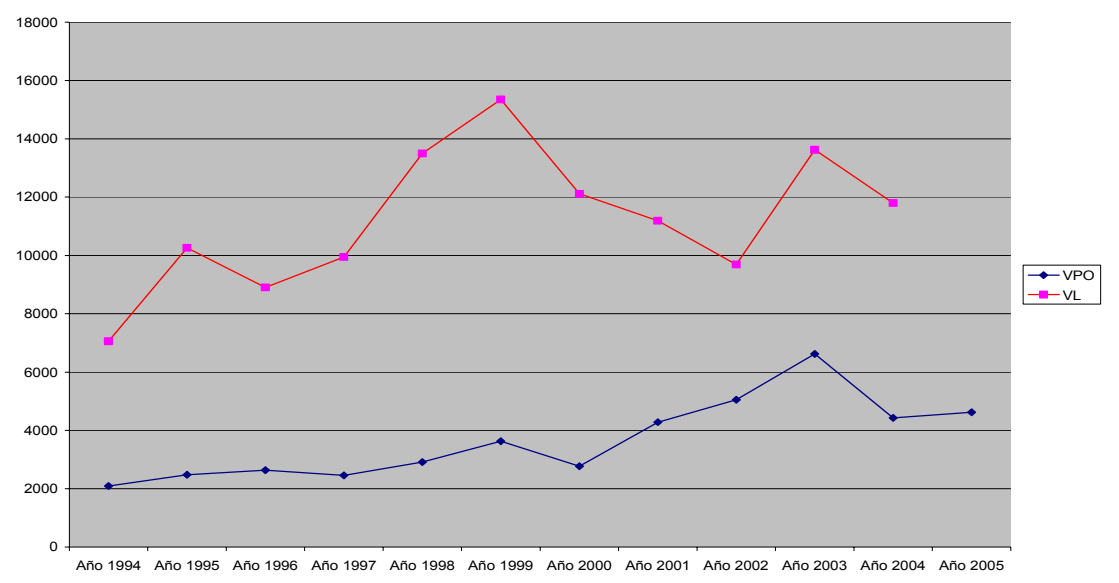

Fuente: Elaboración propia

Se observa con carácter general como tendencia, haciendo abstracción de la puntas de actividad, cómo se ha pasado en la CAPV de una producción de 2.000 viviendas protegidas desde el año 1994 hasta alcanzar una media de 4.500 a 5.000 viviendas anuales en los años 2003 a 2005 - algo lógico si se considera que la introducción de las reservas de suelo para vivienda protegida en los planes urbanísticos ha sido progresiva y, por lo tanto, también diferida en el tiempo -.

En términos relativos, midiendo el peso de la vivienda protegida respecto al total de la producción de vivienda en la CAPV, tenemos lo siguiente:

\footnotetext{
${ }^{12}$ Los datos han sido objeto de publicación en UDALPLAN 2005.

${ }^{13}$ El Departamento de Vivienda calcula que una oferta sostenida de vivienda protegida en torno a las 10.000 unidades anuales, daría respuesta a las necesidades registradas en acceso a la vivienda en un plazo aproximado de 10 a 12 años. Si se calcula que la media de vigencia restante de los planes urbanísticos puede situarse en torno a los 4 años, la cuantificación de la oferta puede considerarse suficiente a medio y largo plazo.
} 


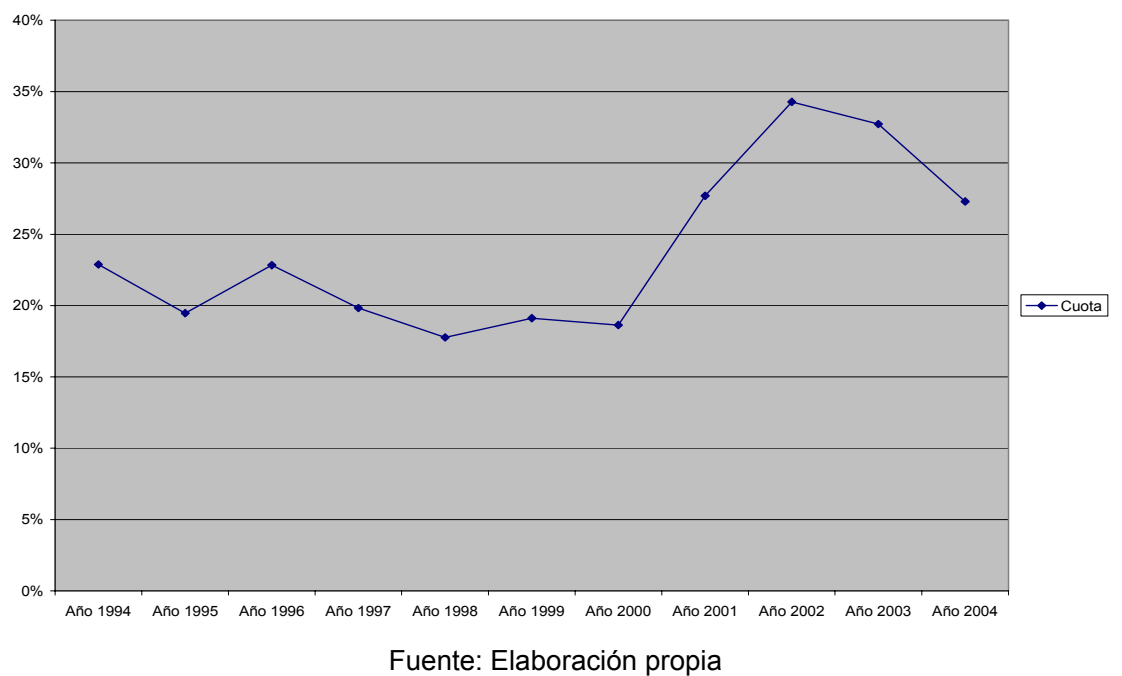

Efectivamente, confirmando la tendencia marcada por los números absolutos de producción de vivienda, se observa también cómo el peso relativo de la vivienda protegida ha crecido desde una media del $20 \%$ en los años 1994-1998 hasta alcanzar una media del 31\% en los últimos cuatro años analizados, lo que confirma la tendencia anteriormente apuntada.

De forma comparativa con otra Comunidades Autónomas estos resultados obtenidos en la CAPV de oferta de vivienda protegida suponen lo siguiente a nivel estatal:

\begin{tabular}{|c|c|c|c|c|c|c|c|c|c|c|}
\hline & \multicolumn{3}{|c|}{ ACUMULADO ENE 02- DIC 05} & \multirow{2}{*}{$\begin{array}{c}\text { CENSO } \\
2001\end{array}$} & \multirow{2}{*}{$\begin{array}{l}\text { vpo por mil } \\
\text { habitantes }\end{array}$} & \multirow{2}{*}{$\begin{array}{c}\text { libres por mil } \\
\text { habitantes }\end{array}$} & \multirow{2}{*}{$\begin{array}{c}\% \text { vpo sobre total } \\
\text { estado }\end{array}$} & \multirow{2}{*}{$\begin{array}{c}\% \text { libres sobre } \\
\text { total estado }\end{array}$} & \multirow{2}{*}{$\begin{array}{l}\text { CUOTA MERCADO } \\
\text { VPO CCAA }\end{array}$} & \multirow{2}{*}{$\begin{array}{l}\text { CUOTA MERCADO } \\
\text { LIBRES CCAA }\end{array}$} \\
\hline & VPO & LIBRES & TOTAL & & & & & & & \\
\hline TOT. EST & 239.156 & 2.629 .034 & 2.932 .334 & 40.847 .371 & 5,85 & 64,36 & $100,00 \%$ & $100,00 \%$ & $8,16 \%$ & $89,66 \%$ \\
\hline$\overline{\text { ANDALUCIA }}$ & 46.667 & 559.215 & 605.882 & 7.357 .558 & 6,34 & 76,01 & $19,51 \%$ & $21,27 \%$ & $7,70 \%$ & $92,30 \%$ \\
\hline ARAGON & 8.481 & 59.478 & 67.959 & 1.204 .215 & 7,04 & 49,39 & $3,55 \%$ & $2,26 \%$ & $12,48 \%$ & $87,52 \%$ \\
\hline ASTURIAS & 4.462 & 59.079 & 63.541 & 1.062 .998 & 4,20 & 55,58 & $1,87 \%$ & $2,25 \%$ & $7,02 \%$ & $92,98 \%$ \\
\hline BALEARES & 1.901 & 41.217 & 43.118 & 841.669 & 2,26 & 48,97 & $0,79 \%$ & $1,57 \%$ & $4,41 \%$ & $95,59 \%$ \\
\hline CANARIAS & 7.275 & 124.256 & 131.531 & 1.694 .477 & 4,29 & 73,33 & $3,04 \%$ & $4,73 \%$ & $5,53 \%$ & $94,47 \%$ \\
\hline$\overline{\text { CANTABRIA }}$ & 1.668 & 39.486 & 41.154 & 535.131 & 3,12 & 73,79 & $0,70 \%$ & $1,50 \%$ & $4,05 \%$ & $95,95 \%$ \\
\hline CAST-LA MANCHA & 12.071 & 148.404 & 160.475 & 1.760 .516 & 6,86 & 84,30 & $5,05 \%$ & $5,64 \%$ & $7,52 \%$ & $92,48 \%$ \\
\hline CAST-LEON & 8.994 & 156.005 & 164.999 & 2.456 .474 & 3,66 & 63,51 & $3,76 \%$ & $5,93 \%$ & $5,45 \%$ & $94,55 \%$ \\
\hline CATALUNA & 19.198 & 401.150 & 420.348 & 6.343 .110 & 3,03 & 63,24 & $8,03 \%$ & $15,26 \%$ & $4,57 \%$ & $95,43 \%$ \\
\hline EXTREMADURA & 9.932 & 39.915 & 49.847 & 1.058 .503 & 9,38 & 37,71 & $4,15 \%$ & $1,52 \%$ & $19,92 \%$ & $80,08 \%$ \\
\hline$\overline{\text { GALICIA }}$ & 14.651 & 147.661 & 162.312 & 2.695 .880 & 5,43 & 54,77 & $6,13 \%$ & $5,62 \%$ & $9,03 \%$ & $90,97 \%$ \\
\hline MADRID & 37.927 & 250.429 & 288.356 & 5.423 .384 & 6,99 & 46,18 & $15,86 \%$ & $9,53 \%$ & $13,15 \%$ & $86,85 \%$ \\
\hline MURCIA & 8.750 & 143.684 & 152.434 & 1.197 .646 & 7,31 & 119,97 & $3,66 \%$ & $5,47 \%$ & $5,74 \%$ & $94,26 \%$ \\
\hline LA RIOJA & 3.282 & 21.405 & 24.687 & 276.702 & 11,86 & 77,36 & $1,37 \%$ & $0,81 \%$ & $13,29 \%$ & $86,71 \%$ \\
\hline COM. VALENCIANA & 26.581 & 352.147 & 378.728 & 4.162 .776 & 6,39 & 84,59 & $11,11 \%$ & $13,39 \%$ & $7,02 \%$ & $92,98 \%$ \\
\hline PAIS VASCO & 18.127 & 52.264 & 70.391 & 2.082.587 & 8,70 & 25,10 & $7,58 \%$ & $1,99 \%$ & $25,75 \%$ & $74,25 \%$ \\
\hline NAVARRA & 8.975 & 29.825 & 38.800 & 555.829 & 16,15 & 53,66 & $3,75 \%$ & $1,13 \%$ & $23,13 \%$ & $76,87 \%$ \\
\hline CEUTA & 0 & 1.352 & 1.352 & 71.505 & 0,00 & 18,91 & $0,00 \%$ & $0,05 \%$ & $0,00 \%$ & $100,00 \%$ \\
\hline MELILLA & 214 & 2.062 & 2.276 & 66.411 & 3,22 & 31,05 & $0,09 \%$ & $0,08 \%$ & $9,40 \%$ & $90,60 \%$ \\
\hline
\end{tabular}

Fuente: Departamento de Vivienda y Asuntos Sociales. Gobierno Vasco ${ }^{14}$

Se observa cómo País Vasco y Navarra son las Comunidades Autónomas donde la actividad de construcción residencial se podría calificar de "más social" y donde el equilibrio entre el peso de la vivienda libre y de la vivienda de protección es más equilibrada.

En resumidas cuentas, aunque el trabajo que queda por hacer en materia de vivienda es ingente, los resultados positivos de las políticas públicas de vivienda tanto en términos cuantitativos, cualitativos y comparativos son evidentes. Ello ha podido deberse no sólo a la cobertura legislativa que supone la Ley 17/1994, cuyo efecto positivo es innegable, sino

\footnotetext{
${ }^{14}$ Los datos han sido extraídos del Consejo Superior de Arquitectos de España.
} 
también a la apuesta decidida de las administraciones autonómica y local en aras a desarrollar políticas activas en este sentido.

En otro orden de cosas de índole completamente distinto, a partir de la entrada en vigor de la Ley estatal 6/1998 de Suelo y Valoraciones y la fijación por esta del método de valoración residual como el sistema de determinación del valor del suelo, la técnica de imposición de reservas para vivienda protegida se convirtió además en una forma interesante de "modalizar" sus efectos perversos por la remisión que hace este método a valores "de mercado" para determinar el precio del suelo bruto. Este efecto resulta especialmente interesante en su aplicabilidad al suelo urbanizable con condiciones de desarrollo ${ }^{15}$.

Así, en la medida que en los ámbitos residenciales el aprovechamiento urbanístico obtenible por la propiedad del suelo se debe materializar legal y obligatoriamente en vivienda protegida, el margen de discrecionalidad que supone la remisión a "valores de mercado" es menor porque la vivienda protegida está excluida de los dinamismos especulativos del mercado. Si además consideramos que el valor máximo repercutible por los conceptos de suelo y urbanización en las viviendas protegidas también está determinado normativamente, partiendo de la fórmula matemática de valoración residual en un suelo urbanizable obtenemos lo siguiente:

$\mathrm{VS}=0,71 \mathrm{VV}-\mathrm{CC}-\mathrm{CU}{ }^{16}$

Si introducimos la obligación de reservar suelo para vivienda protegida y consideramos el valor máximo repercutible por suelo para la vivienda protegida tenemos lo siguiente:

$\mathrm{VV}=0,65 \mathrm{VVP}+0,35 \mathrm{VVL}$ - se parte de las reservas obligatorias por la Ley 17/1994 -

$V S=V S L+V S P$ siendo $V S P=0,1 V V P^{17}$

De este modo, volviendo a la fórmula original obtenemos lo siguiente:

$\mathrm{VSL}+0,1 \mathrm{VVP}=0,71(0,35 \mathrm{VVL}+0,65 \mathrm{VVP})-\mathrm{CC}-\mathrm{CU}$ o lo que es lo mismo

$V S L=0,71(0,35 \mathrm{VVL}+0,65 \mathrm{VVP})-0,1 \mathrm{VVP}-\mathrm{CC}-\mathrm{CU}$

Si partimos de la base que debemos obtener el valor del suelo no protegido - VSL - y que los conceptos de construcción - CC -, urbanización - CU - y valor en venta de la vivienda protegida - VVP - son conceptos que vienen dados bien por el planeamiento, para los primeros, bien por la normativa, para los segundos, el peso que la variable de "valor en venta de vivienda libre" - VVL y sometida a las variables del mercado - tiene para la determinación del valor residual del suelo es francamente más limitado que en la fórmula original.

Finalmente, no podemos concluir este apartado sin resaltar las principales objeciones que se oponían desde diferentes ámbitos a las políticas de vivienda desarrolladas en la CAPV y que fueron tenidas en cuenta a la hora de abordar la aprobación de la nueva legislación urbanística. Estas críticas, resumidamente, son las siguientes:

\footnotetext{
${ }^{15}$ El grupo parlamentario vasco ARALAR realizó en la ponencia parlamentaria una defensa a ultranza de la técnica de imposición de reservas de vivienda protegida en suelo urbanizable al entender que dicha técnica no sólo se traducía en más oferta de vivienda protegida sino que además suponía una forma de influir desde el ámbito de lo público en los "valores de mercado" a los que se remitía la legislación estatal de valoraciones.

${ }^{16}$ VS es valor del suelo, VV es valor en venta, CC es coste de construcción, CU significa coste de urbanización. Por otra parte, VSP significa valor del suelo protegido y VSL del suelo de vivienda libre. VVP supone valor en venta de las viviendas protegidas y VVL de las viviendas libres.

${ }^{17}$ Los Jurados Territoriales de Expropiación interpretan habitualmente que el $20 \%$ máximo de repercusión de suelo urbanizado para vivienda protegida se debe desglosar un 50\% imputable al valor del suelo bruto y el restante $50 \%$ al coste de urbanización.
} 
1. La imposición de la obligación legal de calificación de suelo sólo a los municipios de más de 7.000 habitantes suponía abrir una brecha importante entre esos municipios y, especialmente, los de tamaño medio - a partir de 2.000 habitantes -. Ello no tenía demasiado sentido desde el momento en que las mutuas influencias entre los municipios de una misma área funcional, independientemente de su tamaño poblacional, eran evidentes. Se hacía necesario, por lo tanto, practicar una extensión generalizada de la obligación de reserva de suelo a todos los municipios que no tuvieran carácter rural.

2. El cumplimiento de los estándares de vivienda protegida, se practicaba sobre la base de las figuras tradicionales de protección oficial, que señalaban ciertos límites de ingresos para acceder una vivienda protegida. Desde el sector se reclamaba entonces la extensión de la protección a otros sectores de población - de clase media fundamentalmente - y que habían quedado repentinamente desprotegidos y excluidos del mercado libre por la acusada tendencia al alza de los precios en este mercado.

3. La presencia de la figura de la vivienda protegida en alquiler es escasa. A pesar de que aproximadamente la mitad del total de la oferta del mercado de alquiler en la CAPV está intervenido por la administración - básicamente autonómica - y es puesto por esta a disposición de los demandantes a precios protegidos, su peso cuantitativo todavía es limitado.

4. La competencia en la regulación de figuras de vivienda protegida debe dar mayor peso y presencia a la administración local que, en el ejercicio de las potestades de la función pública urbanística - planeamiento y ejecución básicamente -, tiene conocimiento de primera mano tanto de las posibilidades de intervención en su territorio como del segmento de demanda local al que debe atenderse.

Con carácter independiente del juicio personal que cada cual pueda esgrimir respecto a estos argumentos, este y otros debates en torno al urbanismo y la vivienda tuvieron una presencia muy evidente en los trabajos de discusión parlamentaria de la ley urbanística vasca.

Finalmente, para concluir este apartado sobre la Ley 17/1994, señalar que la norma también preveía una reducción de plazos en la tramitación de los instrumentos de planeamiento y gestión. ${ }^{18}$

Las leyes de medidas urgentes tras la STC 61/1997. La Ley 5/1998, de 6 de marzo, de Medidas Urgentes en materia de Régimen del Suelo y Ordenación Urbana. La Ley 11/1998, de 20 de abril, de modificación de la ley por la que se determina la participación de la comunidad en las plusvalías generadas por la acción urbanística. La STC 54/2002, de 20 de Febrero.

Como ya ha quedado expuesto anteriormente, el fallo de la Sentencia 61/1997 del Tribunal Constitucional por el que se declaraban nulos de pleno derecho la mayor parte de los artículos del Texto Refundido de 1992 sobre Régimen del Suelo y Ordenación Urbana tuvo una incidencia muy importante en aquellas Comunidades Autónomas que, como el País Vasco, habían optado por referir su legislación general en materia de urbanismo a la legislación estatal, por vía supletoria. La reacción por parte de las Comunidades Autónomas fue muy dispar ante tal evento. La CAPV optó por aprobar una serie de "leyes puente" en tanto se configuraba con relativa agilidad una ley urbanística propia - y que posteriormente ha tardado casi diez años en llegar -.

\footnotetext{
${ }^{18}$ Concretamente, la ley se refería a la tramitación de Planes Parciales, Especiales y Estudios de Detalle así como expedientes de reparcelación y funcionamiento del sistema de compensación.
} 
Las leyes citadas más arriba son dos ejemplos de dicha técnica legislativa. La Ley 5/1998 se limitó a cubrir algunos problemas que la remisión al Texto Refundido de 1976 generaba en algunos aspectos, a saber: Proliferación del uso de vivienda unifamiliar en suelos no urbanizables, la regulación de los núcleos rurales como particularidad de los asentamientos rurales tradicionales en la Comunidad Autónoma y la cobertura jurídica a la calificación urbanística del uso de vivienda protegida. Por otra parte, el legislador aclaró el panorama generado por la confusión en lo que refiere a qué institución debía entenderse competente para la aprobación del planeamiento de desarrollo y reguló aspectos de gestión y disciplina imprescindibles para un correcto funcionamiento de los planes urbanísticos entonces vigentes.

Más importancia tiene a nuestro juicio, por lo que de paso adelante supone respecto a la situación jurídica estatal en aquellos momentos, la apuesta del legislador vasco en la Ley 11/1998 en lo que refiere a la consideración de la existencia o no de obligación de cesión de aprovechamiento urbanístico en los suelos urbanos consolidados cuando estos son objeto de plusvalía urbanística - aspecto no aclarado en la vigente Ley estatal 6/1998 de Suelo y Valoraciones $-{ }^{19}$.

Como ya se observa a primera vista, esta norma no distinguía los supuestos de suelo urbano consolidado y no consolidado y, por tanto, exigía la cesión de aprovechamiento indistintamente a todo el suelo urbano. Además también extendía la obligación de cesión a todas las actuaciones de rehabilitación con carácter independiente de la clasificación del suelo urbano sobre el que se asentaba como consolidado o no.

Estos fueron los argumentos esgrimidos por el Abogado del Estado en el recurso de inconstitucionalidad 3550/1998 que se presentó contra esta norma. Por el contrario, los letrados del Gobierno y del Parlamento Vasco opusieron que la distinción entre suelo urbano consolidado y no consolidado no es criterio suficiente para determinar la existencia o no de plusvalías y de la obligación de cesión. Por otra parte, se esgrimió que la definición de suelo urbano consolidado o no consolidado era un aspecto netamente urbanístico cuya competencia le correspondía por tanto a la CAPV.

El fondo del asunto ya había sido enjuiciado previamente por el Tribunal Constitucional en su Sentencia 164/2001, de 11 de julio ${ }^{20}$. Haciendo abstracción de otros aspectos, la Sentencia termina concluyendo que es lícito al legislador estatal, sobre la base de la competencia en la igualación de todos los españoles en el ejercicio de sus derechos de propiedad urbana, excluir de cesión obligatoria de aprovechamiento a determinados propietarios con carácter independiente a la existencia o no de plusvalías urbanísticas - algo que parece estar en abierta contradicción con el mandato del artículo $47 \mathrm{CE}-^{21}$. La Sentencia declaró entonces inconstitucional la norma en el sentido de que se debía interpretar que las cesiones no podían ser obligatorias a los propietarios de suelo urbano consolidado.

No obstante, la Sentencia en su Fundamento Jurídico Quinto afirma que la declaración estatal de no existencia de obligación de cesión de aprovechamiento en suelo urbano consolidado, no supone limitación alguna a cada Comunidad Autónoma para definir "en los límites de la

\footnotetext{
${ }^{19}$ El apartado primero del artículo único de la Ley 11/1998 rezaba de la siguiente forma: "Los propietarios de suelo urbano deberán ceder obligatoria y gratuitamente al Ayuntamiento el diez por ciento del aprovechamiento urbanístico lucrativo del ámbito correspondiente libre de cargas de urbanización. En el supuesto de obras de rehabilitación, únicamente corresponderá al Ayuntamiento el diez por ciento del incremento de aprovechamiento urbanístico sobre el anteriormente edificado."

${ }^{20}$ Ver Fundamento Jurídico 20 de la citada Sentencia del Tribunal Constitucional.

${ }^{21}$ Concretamente el texto de la STC 54/2002 dice así en su Fundamento Jurídico 4: " De esta forma, la hipotética existencia de plusvalías urbanísticas en suelo urbano consolidado, cuya realidad no corresponde dilucidar a este Tribunal, no excluye a priori una norma estatal que alivie de cesiones a sus propietarios”.
} 
realidad" qué debía entenderse por suelo urbano consolidado y qué no. Con ello, se planteó la duda de si la tacha de inconstitucionalidad se hubiera podido salvar si el legislador vasco de 1998 hubiera asociado el carácter de suelo urbano no consolidado a cualquier supuesto de existencia de plusvalía urbanística en suelo urbano, esto es básicamente, operaciones de levante y de rehabilitación.

Evidentemente, el mismo debate también se suscitó en los trabajos parlamentarios de redacción de la Ley vasca 2/2006 de Suelo y Urbanismo, aspecto sobre el que habremos de volver más adelante.

\section{La Ley 20/1998, de 29 de junio, de Patrimonios Públicos de Suelo ${ }^{22}$.}

La situación jurídica creada tras la permanencia en vigor por la Sentencia del Tribunal Constitucional 61/1997 de determinados artículos inconexos del Texto Refundido de 1992 referidos a los Patrimonios Municipales de Suelo - concretamente, artículos 276 y 280 - y la proliferación de determinados recursos planteados por particulares ante lo que se entendía la ilegal inacción administrativa en este terreno, hizo conveniente disponer de una legislación desarrollada sobre esta materia. Inicialmente, fue aprobada en 1997 una ley sobre la obligatoria consignación de cantidades económicas en los presupuestos municipales con este fin para posteriormente abordar en 1998 una regulación más integrada de esta institución.

No se puede perder de vista que la ya existencia de una obligación de reserva de suelo para vivienda protegida por la Ley 17/1994, inclinaba a algunos operadores urbanísticos a afirmar que en la CAPV la institución de los Patrimonios Municipales de Suelo debería orientarse más al desarrollo armónico de los pueblos y ciudades que a la construcción de vivienda protegida ${ }^{23}$. De hecho, podría decirse sin miedo error que la opción legislativa de hacer descansar la seguridad de la existencia de vivienda protegida en los desarrollos urbanísticos pasó de formar parte de los contenidos propios de la intervención administrativa a formar parte de los planes urbanísticos "por imperativo legal". De ahí el empeño confeso del legislador en su Exposición de Motivos en extender los destinos posibles de los patrimonios públicos de suelo a la "ordenación de las ciudades" como, por ejemplo, la adquisición y ordenación de suelos industriales de interés público y para la ubicación de infraestructuras y equipamientos públicos. Por el contrario, otras posiciones políticas interpretaron que, en un contexto de carestía e inaccesibilidad de vivienda, no era legítimo desviar los recursos materiales y económicos municipales de los patrimonios de suelo a otros fines que no fuera la construcción de vivienda protegida.

Nuevamente, la financiación municipal, verdadero "caballo de batalla" de las políticas públicas de suelo, se convertía en el principal escollo del consenso en torno a esta polémica ley.

En lo que refiere a sus contenidos, la Ley recogía en buena medida los instrumentos y herramientas de intervención administrativa en el mercado del suelo que ya se recogían en el Texto Refundido de 1992 actualizando alguno de sus contenidos. Así, se detallaron los recursos económicos y materiales del patrimonio municipal de suelo y se estableció una obligación de consignación presupuestaria para los municipios de más de 7.000 habitantes. Así mismo, se especificaron los destinos y aplicaciones posibles marcando la preferencia - sin

\footnotetext{
${ }^{22}$ La Ley fue publicada en el BOPV número 132, de 15 de julio

${ }^{23}$ El documento aprobado por la Asociación de Municipios Vascos, EUDEL "Más vivienda, más ciudad" (Julio 2004) refleja en buena medida este debate.
} 
determinar su cuantía económica - hacia la vivienda protección oficial pero haciéndolo compatible con otros destinos diferentes "de ordenación de la ciudad" como son ${ }^{24}$ :

- Adquisición y promoción pública de suelo para actividades económicas

- Obras de urbanización y ejecución de sistemas generales

- Construcción de equipamientos colectivos u otras instalaciones de uso público y ámbito municipal.

- Operaciones de iniciativa pública de rehabilitación de vivienda o renovación urbana.

- Rehabilitación del patrimonio histórico o cultural

- Operaciones de conservación, protección o recuperación del medio físico natural en zonas declaradas de protección.

Este listado de destinos posibles de los recursos municipales afectos al patrimonio municipal dan buena fue, por una parte, de la amplitud y flexibilidad con la que se acordó con el mundo municipal la coexistencia de fines diferentes al propio de la construcción de viviendas de protección oficial y, por otra, de las necesidades que los ayuntamientos entendían urgente cubrir.

Con el mismo espíritu de flexibilidad, en aquella ley se habilitaba expresamente la enajenación de los bienes del patrimonio municipal tanto vía concurso como subasta - reproduciendo sin más el sistema de enajenación de bienes y de derechos existente en la legislación local -.

Por otra parte, se configuraban con bastante amplitud la posibilidad de constitución de reservas, el acceso a la expropiación forzosa como forma de obtención y el ejercicio de los derechos de tanteo y retracto sobre los bienes y derechos así delimitados.

A la hora de hacer una concreta valoración sobre lo que ha supuesto en la práctica municipal esta institución, lo cierto es que el panorama es bastante desolador. Ello posiblemente se deba a diferentes factores, algunos de ellos ajenos al propio mundo municipal como pueden ser la financiación municipal, el inestable mundo de las valoraciones de suelo y la regulación legislativa en materia de reversión expropiatoria con destino a los fines del patrimonio público de suelo.

Para finalizar este apartado, haremos una breve referencia a la reciente publicación de un informe por parte del Tribunal Vasco de Cuentas Públicas ${ }^{25}$ en el que, referente a los patrimonios públicos de suelo se extraen las siguientes cifras:

\begin{tabular}{|l|c|c|c|}
\hline & SI & NO & NO CONTESTA \\
\hline Constitución inventario PMS (obligatorio) & 5 & 9 & 23 \\
\hline Consignaciones presupuestarias (<7.000 hab.) & 9 & - & 17 \\
\hline Reservas municipales de suelo (optativo) & 2 & 15 & 20 \\
\hline & & & \\
\hline
\end{tabular}

Por otra parte, en el año 2004 sólo un Ayuntamiento de los cuatro que han tenido bajas en el inventario manifiesta destinar los mismos a vivienda protegida. En todo caso, tampoco pueden

\footnotetext{
${ }^{24}$ El desarrollo concreto de esos destinos bajo el amparo de "otros fines de interés social" se puede encontrar en el artículo 7 de la citada Ley.

${ }^{25}$ TRIBUNAL VASCO DE CUENTAS PUBLICAS (TVCP): "Análisis transversal de los Ayuntamientos de la Comunidad Autónoma de Euskadi comprendidos entre 5.000 y 20.000 habitantes". 2004
} 
extraerse excesivas conclusiones de un muestreo donde la respuesta al cuestionario ha sido tan escasa. Lo único evidente en este panorama es la enorme confusión que en el mundo municipal, 8 años después de la entrada en vigor de la ley, produce el cumplimiento de sus determinaciones.

El dibujo institucional y competencial en materia urbanística. La Ley $5 / 1993$ de Modificación de Relaciones entre las Instituciones Comunes y los órganos forales de sus Territorios Históricos $\underline{\underline{26}}$

La Constitución Española de 1978 ampara los derechos de determinados Territorios Históricos - País Vasco y Navarra, concretamente - y respeta por tanto sus competencias en base al fenómeno histórico de la foralidad. Mientras Navarra, se constituye en Comunidad Foral haciendo coincidir el ámbito territorial de la Comunidad Autónoma y el Territorio Histórico, en la Comunidad Autónoma del País Vasco se reconocen tres Territorios Históricos (Vizcaya, Gipuzkoa y Álava). Surge por tanto en la CAPV la necesidad de articular un complejo panorama institucional y realizar un reparto competencial entre los órganos ejecutivos de la Comunidad Autónoma y de los respectivos Territorios Históricos.

En materia urbanística, competencia que había asumido como exclusiva el Estatuto de Autonomía en su artículo 10.31, la Ley 27/1983 de Relaciones entre las Instituciones Comunes y los órganos forales de sus Territorios Históricos, modificada con efectos aclaratorios por la Ley 5/1993, disponía que era competencia de los Territorios Históricos - las respectivas Diputaciones Forales - la aprobación de todos los instrumentos de ordenación urbanística con la única excepción del planeamiento especial en desarrollo de competencias propias del Gobierno Vasco. De esta forma, la competencia de aprobación definitiva de instrumentos de ordenación territorial quedó residenciada en el Gobierno Vasco mientras la aprobación definitiva de instrumentos de ordenación urbanística quedó en manos de las respectivas Diputaciones Forales. Para asegurar la debida coordinación entre las materias territorial y urbanística se instituyó que fuera la Comisión de Ordenación del Territorio del País Vasco entidad dependiente del Gobierno Vasco - la que informara con carácter preceptivo y vinculante sobre los aspectos de incidencia territorial. Mientras los instrumentos de ordenación territorial no hubieren sido aprobados definitivamente, dicho control sobre el planeamiento urbanístico del Gobierno Vasco se circunscribía expresamente a materias como la cuantificación de los desarrollos previstos tanto residenciales, industriales como de servicios, así como aquellos aspectos con incidencia sobre las infraestructuras, recursos, actividades y materias de orden sectorial y que no fueran competencia de los entes forales.

Como se puede observar, a través de estas legislaciones el mundo local fue apartado de la competencia urbanística. Por otra parte, la proliferación de normativas sectoriales vinculantes para los planeamientos urbanísticos supuso la reducción del campo de acción de los propios Ayuntamientos en el diseño y planificación de sus pueblos y ciudades. A todo ello hay que sumar la confusión que existía, ya citada anteriormente, sobre los límites de las escalas territoriales y locales en un contexto de complejidad institucional y de escasez superficial del territorio a ordenar de modo que "los controles de oportunidad" por parte de las instituciones supralocales excedían en ocasiones el ámbito de la ordenación territorial entrando, en algunas ocasiones, en consideraciones de competencia estrictamente municipal ${ }^{27}$.

\footnotetext{
${ }^{26}$ Esta ley se publicó en el Boletín Oficial del País Vasco de 20 de julio de 1993 (número 136)

${ }^{27}$ La polémica sobre los concretos límites en el ejercicio de la competencia supramunicipal en materia de aprobación de planes urbanísticos ya había sido objeto de análisis y resolución por la jurisprudencia del Tribunal Supremo (Ver,
} 
Todos estos factores enunciados contribuyeron a generar un creciente malestar en el mundo municipal. La percepción era entonces que la "función pública urbanística" se estaba resquebrajando toda vez que no existía campo de acción suficiente para los Ayuntamientos en materia de ordenación urbanística mientras que el campo de acción en materia de ejecución y disciplina era notablemente más amplio. Ello contribuía a generar una sensación en el mundo local de tener un papel de puro "ejecutor" de decisiones ya previamente adoptadas en otras instancias supramunicipales sobre su territorio municipal.

Evidentemente, este ambiente influyó decisivamente en la resolución que, sobre este concreto conflicto, ha dispuesto la Ley 2/2006 de Suelo y Urbanismo del País Vasco.

entre otras, la STS de 18 de Mayo de 1992). Dicha sentencia aclara que en las cuestiones de planeamiento urbanístico no regladas y que no afecten a intereses o proyectos supramunicipales, el juicio de oportunidad realizado por las instituciones supramunicipales no tiene ninguna base jurídica al violar el ámbito propio de la autonomía municipal. 


\section{EJES ESTRATÉGICOS DE LA LEY 2/2006}

\section{$\underline{\text { Introducción }}$}

Del contexto previamente expuesto en este artículo, tanto desde los ámbitos externos a la CAPV como internos de la misma, podríamos resumir como retos y objetivos a abordar por el legislador vasco, al margen de la disposición de una regulación integral e integrada en materia urbanística, los siguientes:

1. Resolución del conflicto en plusvalías urbanísticas y cesión de edificabilidad. Régimen urbanístico del suelo. La clasificación del suelo urbano. Definición del suelo urbano no consolidado y las actuaciones de dotación.

2. Impulso y refuerzo normativo a las políticas públicas de suelo (tanto en materia de vivienda protegida como de actividades económicas). La calificación de suelo para actuaciones protegidas. Especialmente, las políticas de vivienda.

3. La ordenación urbanística. Flexibilización mediante la separación entre la ordenación estructural y pormenorizada. Versatilidad del planeamiento tanto en tipos de planes como en contenido de los mismos.

4. La sostenibilidad urbana. Desarrollo del principio general sobre el desarrollo sostenible. Estándares de densidades máximas y mínimas. Estándares de dotaciones, obligación de mantenimiento. Carácter del suelo no urbanizable.

5. Efectividad en la ejecución de la ordenación urbanística. La programación de actuaciones integradas. El concepto de obra urbanizadora como una obra pública, sometimiento a legislación de contratos y conservación de la misma. Los sistemas de ejecución privados y su funcionamiento. La obligación de edificación y de rehabilitación, herramientas.

6. Reforzamiento de la intervención administrativa en el mercado del suelo. Materialización en suelo, destinos de los PMS y sistema de enajenación. La figura de la reparcelación forzosa y la flexibilidad en la herramienta de las reservas y del resto de figuras de intervención. El derecho de superficie y la dotación residencial protegida.

7. Panorama competencial. Empoderamiento local, papel de las instituciones supramunicipales y acceso a la participación ciudadana. Algunos aspectos de la centralidad del planeamiento y la información urbanística.

Como se observará, todos los aspectos enunciados como problemáticos en la parte anterior de este artículo - las políticas de suelo y vivienda, el problema de la sostenibilidad, la burocracia urbanística, la inejecución de las determinaciones de la ordenación urbanística, la irrelevancia de las administraciones públicas en el mercado de suelo, etc. - buscan la orientación de su solución sobre la base de reforzar el papel de las administraciones públicas, especialmente las locales, en todas esas materias en un claro ejercicio de recuperación del Urbanismo como función pública.

Es de obligación añadir en este momento que el borrador de pacto de suelo que fue presentado por el Ministerio de Vivienda a las Comunidades Autónomas, sobre la base de compartir varias de las preocupaciones aquí señaladas, recogía compromisos de diversa índole. Entre ellos, compromisos de reforma tanto para el legislador estatal como para el legislador autonómico de sus respectivas legislaciones en materia de suelo y de urbanismo. 
El concepto de "participación de la comunidad" en las plusvalías generadas por la acción urbanística. La visión reduccionista limitada a la cesión de un porcentaje de la edificabilidad urbanística

Una de las primeras cuestiones que nos tendríamos que plantear es hasta qué punto el artículo $47 C E$ ha querido perpetuar la relación existente entre las Administraciones Públicas y los propietarios de suelo en relación con la generación de las plusvalías urbanísticas.

Tradicionalmente, dicha participación de la comunidad se ha venido materializando a través de la llamada "cesión" por parte de los propietarios de suelo de un porcentaje de sus derechos urbanísticos a favor de la Administración. Antes que nada, habría que realizar una primera matización en el sentido de que dicho acto no es propiamente una "cesión" de derechos urbanísticos de la propiedad del suelo a favor de la Administración, toda vez que dichos derechos pertenecen a la "Comunidad" desde un principio de la generación de la plusvalía y no quedan por tanto condicionados a la materialización de la efectiva cesión por parte de la propiedad del suelo. Por ello, el legislador vasco a la hora de regular esta materia habla con claridad en su artículo 27 de "participación de la comunidad en las plusvalías" y no de "obligación de cesión por parte de los propietarios"28.

Por otra parte hay que advertir que es muy discutible que el concepto constitucional de "plusvalías generadas por la acción urbanística" se identifique únicamente con un porcentaje de los "aprovechamientos urbanísticos". Ciertamente, se impone una primera reflexión sobre el objeto sobre el que se ha de materializar dicha participación o, dicho con otras palabras, la plusvalía real generada ¿Cuáles son las plusvalías realmente generadas? ¿Acaso se identifican las mismas con los aprovechamientos o hay también que considerar las cargas reales que resultan precisas para la materialización de dichos derechos? ¿Acaso hay que reconsiderar determinadas técnicas de real y efectiva equidistribución de beneficios y cargas entre la propiedad del suelo y la Administración?

Y ello referido concretamente, por una parte, a la posibilidad de adscripción a una actuación urbanística de cargas de sistemas generales - en cualquier tipo de suelo - cuando dicho sistema general resulta necesario funcionalmente para el correcto funcionamiento en red del nuevo desarrollo urbanístico previsto. A esto viene a responder el artículo 53.1.f) de la Ley vasca de Suelo y Urbanismo que posibilita, a través de su inclusión en la ordenación estructural de un Plan General, la adscripción de un sistema general a un ámbito de ordenación urbanística para la obtención del suelo e incluso financiamiento de su ejecución en determinadas circunstancias.

En esa misma línea de reflexión, se impone también una reflexión respecto a la concreta fórmula para la determinación y actualización de la cuantificación de dichas plusvalías urbanísticas mediante la técnica de "coeficientes de homogeneización". Así, suele ser habitual que dichos coeficientes queden desactualizados con el paso del tiempo entre el momento de su fijación en el planeamiento y el momento del acto reparcelatorio. Por ello, el artículo 56.1.f) de la ley vasca considera el establecimiento de dichos coeficientes como una determinación de planeamiento pormenorizado y no de Plan General. Además, permite la alteración de sus coeficientes numéricos al concreto acto y momento de la reparcelación, que es el efectivo momento en el que se opera la equidistribución.

Mención aparte merecen otros dos aspectos que se abordan posteriormente pero que enlazan con la reflexión a que nos referimos en este apartado. Nos referimos concretamente a la

\footnotetext{
${ }^{28}$ Esta denominación de "participación" en vez de "cesión" ha venido siendo tradicional en el legislador vasco desde que se reguló la técnica de esta materia a través de las leyes 3/1997 y 11/1998.
} 
posibilidad del planeamiento urbanístico para calificar y reservar suelos con destino a usos protegidos por la Ley - en referencia tanto a la vivienda protegida como a otros usos urbanísticos de interés económico declarados de interés público - incluso por encima de la estandarización legalmente obligatoria a la que se le da por tanto carácter de mínimo. Ello responde a la idea de que las plusvalías deben poder ser limitadas por el propio planeamiento fijando reservas de suelo para usos urbanísticos débiles por encima de los establecidos legalmente como obligatorios.

Por otra parte, también conviene referir a un apartado expreso la profundización en la posibilidad de separar los supuestos de existencia de plusvalía urbanística y de participación de la comunidad en la misma como se colegía de la jurisprudencia del Tribunal Constitucional de 2001 y 2002. La solución que el legislador vasco de 2006 aporta a esta controversia, suscitada precisamente al calor de una previsión legal autonómica vasca de 1998, se aborda en el apartado siguiente. 
El conflicto entre la existencia de plusvalías urbanísticas y la existencia de obligación de cesión de la edificabilidad.

El artículo 24.2 de la Ley 2/2006 ya deja entrever que el legislador vasco ha querido, como principio general, vincular el ejercicio de los derechos y de los deberes urbanísticos de modo que no sea posible esgrimir unos sin cumplir otros ${ }^{29}$. De este modo, la intención del legislador vasco ha sido, al igual que en 1997 y 1998, la de decantarse por buscar las fórmulas a través de las cuales no fuera posible en ningún caso materializar la plusvalía urbanística sin el cumplimiento de las obligaciones, entre ellas, la de cesión del $10 \%$ de la misma. Ello pasaba por articular legalmente una definición estricta de lo que hubiere de entenderse por "suelo urbano consolidado".

Como hemos citado anteriormente, a partir de la Sentencia del Tribunal Constitucional 54/2002 en contra de la Ley 11/1998 por la que el legislador vasco vinculaba la cesión de edificabilidad urbanística a todo supuesto en suelo urbano, independientemente de su consideración como consolidado o no consolidado, surgió la duda de si dicha tacha de inconstitucionalidad podría ser evitada mediante la categorización por la legislación urbanística del "suelo urbano no consolidado" como aquel suelo urbano que fuere objeto de plusvalía urbanística por cualquier concepto, operaciones de levante u operaciones de rehabilitación.

Dicha posición se argumenta sobre la base de que la atribución por la ordenación urbanística a un suelo urbano de mayor edificabilidad urbanística que la previamente materializada, y con carácter independiente de su grado de urbanización, presupone la quiebra de la relación previamente existente entre la superficie dotacional y la superficie lucrativa. Por lo tanto, el propietario de suelo urbano al que se le atribuye mayor edificabilidad urbanística tendrá, al menos y en todo caso, pendiente con la comunidad el libramiento a su cargo de las cargas de cesión de superficie dotacional suficiente para compensar el incremento de la superficie lucrativa atribuida por la ordenación. Esa obligación pendiente de cumplimiento por parte del propietario de suelo es el motivo para la consideración de su superficie como "no consolidado".

Esa posición es la que finalmente fue incorporada al texto legal. Dicho en otras palabras, la consideración de un suelo urbano como no consolidado en la Ley 2/2006 puede deberse bien a sus condiciones de urbanización bien al grado de consolidación de la edificabilidad previamente existente. Concretamente, el artículo 11.3 b) permite a la ordenación urbanística adscribir superficies de suelo urbano a la clase de suelo urbano no consolidado por concurrir alguna de las siguientes circunstancias:

1. No consolidado por la urbanización:

a) No comprender la urbanización existente todos los servicios exigidos por la ordenación o bien carecer unos y otros de la proporción y dimensiones suficientes para servir a la edificación.

b) Precisar la urbanización existente de renovación, mejora o rehabilitación que deba ser realizada mediante transformación urbanística derivadas de la reordenación o renovación urbana.

2. No consolidado por la superior edificabilidad atribuida por parte de la ordenación urbanística respecto a la previa existente.

\footnotetext{
${ }^{29}$ Concretamente el artículo 24.2 de la Ley 2/2006 dispone lo siguiente: "El cumplimiento de los deberes enunciados es condición previa en cada caso del legítimo ejercicio de las facultades previstas en este título"
} 
El sistema planteado se completa con los artículos 25.2 y 27.3 que, para este último supuesto de suelo urbano no consolidado por la edificación, especifican que los deberes urbanísticos del propietario consisten en la cesión del $10 \%$ del incremento edificabilidad urbanística atribuido a la parcela además del levantamiento de la carga dotacional correspondiente a dicho incremento o su indemnización sustitutoria. El legislador reserva además la definición específica de "actuaciones de dotación" a aquellas que tienen por objeto el cumplimiento de estos deberes pendientes en el suelo urbano no consolidado por la edificabilidad - artículo 137 ${ }^{30}$. Resumiendo, el esquema básico que relacionaría en cada clase de suelo los deberes urbanísticos queda fijado por el legislador vasco de la siguiente forma:

\begin{tabular}{|l|c|c|}
\hline & $\begin{array}{c}\text { Deber de urbanización / } \\
\text { Cesión de dotaciones }\end{array}$ & $\begin{array}{c}\text { Cesión } \\
10 \%\end{array}$ \\
\hline Suelo urbano consolidado & $\mathrm{NO} / \mathrm{NO}$ & $\mathrm{NO}$ \\
\hline Suelo urbano no consolidado urbanización & $\mathrm{SI} / \mathrm{SI}$ o NO & $\mathrm{SI}$ \\
\hline Suelo urbano no consolidado edificación & $\mathrm{SI}$ o NO / SI & $\mathrm{SI}$ \\
\hline Suelo urbanizable - previa sectorización - & $\mathrm{SI} / \mathrm{SI}$ & $\mathrm{SI}$ \\
\hline
\end{tabular}

El aspecto más débil de esta regulación puede consistir en el jurídicamente dudoso encaje de este esquema en la regulación del actual artículo 14 de la Ley 6/1998 de Suelo y Valoraciones en los que parece vincularse el grado de consolidación al "hecho urbanizador" ${ }^{31}$ y no al hecho de la obtención de plusvalía urbanística. No obstante, la previsible desaparición en la futura legislación estatal de esta categoría, contribuiría decisivamente a aclarar este aspecto.

Además, el propio sistema diseñado por el legislador vasco, al vincular la clasificación de suelo urbano como consolidado o no a la atribución pormenorizada de edificabilidad urbanística, se ve obligado a dar carácter de ordenación pormenorizada a dicho acto de clasificación. De esta forma, el artículo 53 sólo atribuye rango de planeamiento general a la clasificación de suelo entre el suelo urbano, urbanizable y no urbanizable y a la clasificación del urbanizable entre sectorizado y no sectorizado. La clasificación del suelo urbano entre consolidado o no consolidado se recoge en el artículo 56.1.c) atribuyendo al mismo el carácter de ordenación pormenorizada. De este modo, la clasificación urbanística del suelo urbano en la legislación vasca se realiza entre el plan general - que separa el suelo urbano del resto del suelo - y el planeamiento especial - que separa el urbano consolidado del no consolidado -. Ello parece romper la regla tradicional de considerar la clasificación urbanística como una determinación reservada al planeamiento general. En opinión personal, ello sólo es explicable desde la consideración de que el legislador vasco nunca ha asumido la categoría del "suelo urbano consolidado por la urbanización" como categoría propia al romper la misma otra regla tradicional como es la de vincular la existencia de plusvalía urbanística al deber de participación de la colectividad en dicha plusvalía.

\footnotetext{
${ }^{30}$ Con ello el legislador vasco parece adelantarse a la futura obligación dimanante del proyecto de ley de suelo del Estado que en su artículo 14.1 b) dispone: "Las actuaciones de dotación, considerando como tales las que tengan por objeto incrementar las dotaciones públicas de un ámbito de suelo urbanizado para reajustar su proporción con la mayor edificabilidad o densidad o con los nuevos usos asignados en la ordenación urbanística a una o más parcelas del ámbito y que no requieran la reforma o renovación integral de la urbanización de este."

31 El párrafo segundo del citado artículo, al referirse a los propietarios del suelo urbano no consolidado habla claramente de "propietarios de terrenos de suelo urbano que carezcan de urbanización consolidada."
} 
Impulso y refuerzo normativo a las políticas públicas de suelo.

Introducción. La calificación de suelo para actuaciones protegidas.

Tradicionalmente, la legislación urbanística tradicional en el modelo español desde 1956 ha separado, a efectos de gestión, los usos lucrativos de los usos públicos y dotacionales en los desarrollos urbanos. El sistema tradicional consistía en habilitar jurídicamente al propietario del suelo para la obtención de los usos lucrativos - que se estimaban de interés estrictamente particular - mientras la administración pública se limitaba a percibir del propietario los terrenos urbanizados que tenían destino al uso de la colectividad por entender que el interés público se concretaba en dichos suelos. La calificación urbanística se hacía también eco de esta distinción.

Posteriormente el legislador comprendió que el interés público no sólo radica en la obtención libre de cargas de urbanización de los suelos dotacionales sino que dicho interés público se debía ampliar hasta asegurar la presencia en los planes urbanísticos de lo que se llaman "usos urbanísticos débiles" - la vivienda protegida, entre ellos -. Estos usos, aunque lucrativos, incorporaban un indudable interés público en su implantación. Para ello, se optó por extender la técnica de exigir por vía legal unos estándares dotacionales en los desarrollos urbanos a la obligada fijación también de estándares que aseguren el destino de una parte de esos suelos para la implantación de dichos "usos urbanísticos débiles". Así mismo, la calificación urbanística también se hizo eco de esta técnica y se pasó a distinguir en los planes urbanísticos entre el uso de "vivienda libre" al uso de "vivienda protegida" asignándoles a cada uso valores de homogeneización diferentes ${ }^{32}$.

Evidentemente, la técnica de calificación de usos diferenciados como, por ejemplo, la vivienda protegida tuvo mucho predicamento en la CAPV donde, por aplicación de la Ley 17/1994 de Medidas Urgentes, se exigía a determinados planeamientos reservar determinados suelos con este fin. La única forma de operar dicha reserva obligatoria era a través de la fijación de calificación urbanística de dichos suelos con el destino de construcción de vivienda protegida.

No obstante, pronto el legislador vasco extendió el razonamiento anterior para habilitar a los planes urbanísticos, mediante esta técnica de la calificación urbanística, con el objeto de la implantación de otros usos lucrativos de interés general de carácter no residencial sino económico. Nos referimos concretamente a la implantación de programas de fomento de la actividad económica de interés público.

Esta opción legislativa también determina que sobre la mayoría de las actuaciones urbanísticas coexistan intereses concurrentes privados y públicos en su desarrollo. Dicho de otra forma, la ejecución de la ordenación urbanística no sólo debe ser imperativa por efecto de su carácter función pública - sino también por el interés público de su contenido - implantación de los "usos urbanísticos débiles"-. Ello tiene su importancia a la hora de abordar el carácter imperativo de la ejecución urbanística en los plazos previstos para ello. La dimensión temporal de la ejecución en los tiempos previstos, a través de la institución de la programación, es otra de las novedades de la ley, aspecto que se abordará más adelante.

Retomando el hilo conductor de este apartado, debemos resaltar el capítulo tercero del título segundo de la Ley 2/2006 se dedica a la calificación urbanística del suelo. Así, el artículo 15 incorpora una definición de la calificación urbanística para posteriormente el artículo 16 entrar a abordar a definir los "usos urbanísticos débiles" a que dicho suelo calificado debe ser

\footnotetext{
${ }^{32}$ La posibilidad de distinguir, bajo la técnica de la calificación, un uso urbanístico específico bajo el epígrafe de vivienda protegida ya se recogía en el Texto Refundido de la Ley de Suelo y Ordenación Urbana de 1992. El legislador vasco recuperó esta posibilidad al amparo de la Ley 5/1998 de medidas urgentes (ver artículo segundo).
} 
destinado, usos que el legislador declara como usos protegidos. Estos usos protegidos son la vivienda protegida $\mathrm{y}$, con carácter novedoso en la legislación vasca, la implantación de actividades económicas que hayan sido declaradas como de fomento o de interés público. Así como la vivienda protegida ya dispone de una normativa reglamentaria que desarrolla su tipología régimen de acceso y precios máximos, por el contrario, las llamadas por la ley "actividades económicas de fomento o de interés público" deberán ser objeto de desarrollo reglamentario por el correspondiente Departamento de Industria o Comercio ${ }^{33}$.

Conviene así mismo destacar dos aspectos cuya relevancia es acusada respecto a la técnica de la calificación urbanística de suelo para usos protegidos y que recoge el propio artículo 16 de la Ley 2/2006. A saber;

a. La superficie e intensidad de la calificación de suelo para usos protegidos la fija el planeamiento urbanístico con sujeción y respeto a los mínimos exigidos en los estándares legales. De este modo, se deja claro que el plan urbanístico es el que fija la superficie de suelo calificada y para qué uso se destinan. Así, el planificador puede superar los estándares legales, que funcionan como unos mínimos.

b. Los suelos que tengan calificación para usos protegidos deberán tener un valor de ponderación asignado específico respecto al resto de los usos lucrativos previstos. Por lo tanto, a la hora de determinar el valor del suelo por el método residual se tendrá en cuenta la intensidad de dicha protección otorgada por el plan y no sólo por la ley en el estándar. Ello permite que la superación de los estándares legales de protección por el planificador urbanístico también se consideren y tengan en cuenta a la hora de determinar el valor del suelo sobre el que dichos usos van a ser implantados ${ }^{34}$.

Esta idea se reitera, a contrario sensu, en el artículo que regula los estándares de vivienda protegida - artículo 80 - que, en su párrafo primero, dispone que el planeamiento urbanístico municipal determinará la reserva de terrenos calificados con destino a viviendas sometidas a algún régimen de protección pública y que, como mínimo, atenderá a los estándares y cuantías que se señalan en los apartados siguientes.

A continuación haremos un repaso de la regulación de los estándares fijados como mínimos por la Ley 2/2006 para vivienda protegida y que tanta polémica suscitó en el debate parlamentario. Para tener un panorama completo, se hará referencia en este estudio a la figura novedosa de los alojamientos dotacionales.

\section{El problema del acceso a la vivienda en la Ley 2/2006}

Una de las críticas que se ha hecho a la Ley 2/2006 - que en opinión de otros es una de sus principales virtudes - es que se ha hablado mucho de vivienda y poco de urbanismo. $O$ dicho de otra forma, que el legislador urbanístico ha visto tenido su punto de mira demasiado orientado al problema residencial a la hora de adoptar decisiones legislativas en materia urbanística. En opinión personal, entiendo que no se podía haber hecho de otra forma toda vez que la vivienda se manifiesta como la principal preocupación de los ciudadanos vascos y que es la propia Constitución Española la que vincula en su artículo

\footnotetext{
${ }^{33}$ Así lo dispone la Disposición Adicional Décima que exige desarrollo reglamentario sobre su régimen jurídico antes de su puesta en práctica. Por ello, tampoco se fijan en la ley unos estándares mínimos de obligación de calificación de suelo con este fin.

${ }^{34}$ El artículo tercero del párrafo 16 dispone literalmente: "Cuando el planeamiento urbanístico municipal califique terrenos para la construcción de viviendas sujetas a algún régimen de protección pública o para la implantación de actividades económicas de fomento o interés público, estas edificaciones se tendrán en cuenta en la determinación ponderada de la edificabilidad urbanística a efectos de la valoración del suelo."
} 
47 el derecho de acceso a la vivienda y el uso del suelo conforme al interés general resultando así proscrita la especulación.

Sea como fuere, la realidad es que el problema de acceso a la vivienda se había constituido en la prioridad en muchas agendas políticas de diferentes instituciones, especialmente de Ayuntamientos. Ello ha convertido la redacción del texto legal en una oportunidad para recuperar el consenso institucional y orientar la actividad urbanística hacia la resolución de este problema ${ }^{35}$.

Ciertamente habían pasado más de diez años desde que, por primera vez en la legislación urbanística comparada en el Estado, la Ley vasca 17/1994 adoptara la técnica de la estandarización para imponer a los planeamientos urbanísticos la reserva obligatoria de suelo para vivienda protegida ${ }^{36}$. Dicha encomienda siempre había correspondido a la ordenación territorial con carácter precedente. En esos más de diez años el resto de las legislaciones urbanísticas habían introducido ya diferentes reservas obligatorias y además el mercado inmobiliario había sufrido fuertes tensiones de precios al alza imposibilitando el primer acceso a la vivienda a importantes sectores de población, especialmente población joven.

Así, la Ley 2/2006 optó, por una parte, por extender la obligación de estándares a la mayor parte de los municipios de la CAPV - más del $93 \%$ de la población vasca habita ahora en municipios obligados al cumplimiento de los estándares - y a hacer más exigente la cuantía de dicha reserva de suelo para vivienda protegida tanto en suelo urbano como en suelo urbanizable sobre la base, principalmente, de la coexistencia de diferentes tipologías de vivienda protegida de regulación autonómica y municipal.

Por otra parte con carácter pionero prácticamente en la legislación urbanística comparada en el Estado se ha dado carta de naturaleza a la figura de los alojamientos dotacionales y que se desarrollará más adelante.

De forma esquemática, la comparativa entre los estándares de la Ley 17/1994 y la Ley 2/2006 son los siguientes:

Ley 17/1994 de Medidas Urgentes

Municipios obligados: 7.000 habitantes

Estándar suelo urbano: $20 \%$

Estándar suelo urbanizable: $65 \%$

Vivienda protegida: Protección Oficial

Alojamientos dotacionales: No previstos
Ley 2/2006 de Suelo y Urbanismo

Municipios obligados: 2.000 habitantes

Estándar suelo urbano: $40 \%$

Estándar suelo urbanizable: $75 \%$

Vivienda protegida: Protección pública

Alojamientos dotacionales: Previstos

Una de las principales novedades, además de las numéricas, es la migración del concepto de "vivienda de protección oficial" hacia el concepto de "vivienda de protección pública" dando así cobertura a la posibilidad de existencia de figuras de protección pública

\footnotetext{
${ }^{35}$ Recordamos que las principales críticas a la política de vivienda no se basaban tanto en sus resultados como en los planteamientos de base sobre los que se basaban. Principalmente, la existencia de una figura única de la vivienda protegida de regulación autonómica - vivienda de protección oficial - frente a la posibilidad de disponer de otras figuras protegidas intermedias en precio entre la vivienda de protección oficial y la vivienda libre así como hacer copartícipes a los entes locales de su regulación. Así mismo otra de las preocupaciones que el legislador ha tenido que enfrentar ha sido la de dar mayor presencia a la vivienda protegida en alquiler y la de extender tanto los porcentajes obligatorios de reserva así como los municipios obligados a practicar la citada reserva.

${ }^{36}$ Un aspecto fuertemente controvertido ha sido la interpretación que el Gobierno Vasco, a través del Decreto 142/1997, realizó de la expresión legal de la Ley 17/1994 que hablaba de viviendas sometidas a cualquier régimen de protección pública. Dicho Decreto en su artículo primero estableció que sólo la vivienda protección oficial reconocida en la legislación sectorial podía dar cumplimiento a dicha obligación de reserva de suelo.
} 
municipal -viviendas tasadas-, reguladas mediante Ordenanza, a las que la ley impone ciertas condiciones ${ }^{37}$ :

1. Todas las viviendas de protección pública - las viviendas de protección oficial y las llamadas viviendas tasadas municipales - tienen el precio máximo regulado públicamente de forma permanente y están, por lo tanto, también con carácter permanente sometidas a los derechos de tanteo y retracto. Así mismo, todas las viviendas de protección pública deben ser adjudicadas mediante un procedimiento de libre concurrencia, con la única excepción de programas de asistencia social y materialización de obligaciones de realojo o retorno. Las diferentes figuras de vivienda protegida resultantes de la ley urbanística serían las siguientes ${ }^{38}$ :

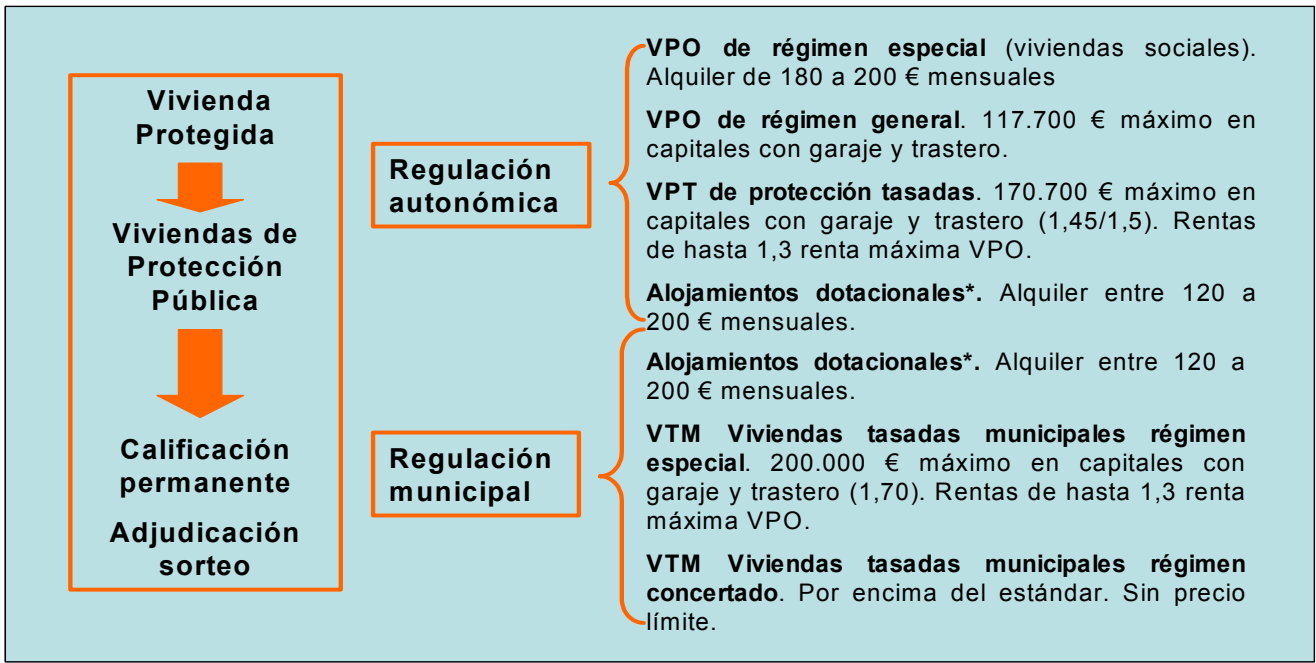

Fuente: Elaboración propia

2. Hasta un máximo de un $20 \%$ de las reservas citadas anteriormente tanto para suelo urbano y urbanizable, la vivienda de protección oficial de régimen general puede ser sustituida por la vivienda de régimen tasado en el supuesto de que la calificación urbanística así lo dispusiera. Esta vivienda de régimen tasado - de regulación autonómica - también puede ser sustituida por viviendas tasadas municipales en el supuesto de que esta figura estuviera ya prevista en la correspondiente Ordenanza y así se previera en el acto de calificación.

3. Por encima de los estándares, el plan urbanístico en la calificación puede optar por ampliar la presencia de cualquiera de estas figuras protegidas de vivienda.

Para finalizar, debemos citar en este apartado la introducción en la Disposición Final Cuarta de la Ley 2/2006 el compromiso de todas las instituciones públicas vascas en fomentar la oferta de vivienda en régimen de alquiler. Para ello, dichas instituciones se comprometen al destino de parte de las reservas de suelo previstas en la ley para vivienda protegida para su puesta a disposición en el régimen de alquiler social o arrendamiento protegido.

\footnotetext{
${ }^{37}$ Véase la Disposición Adicional Octava de la Ley 2/2006.

${ }^{38}$ Los precios máximos de las viviendas protegidas están actualizados a Julio de 2006 y se suministran, por tanto a efectos de comparación y estimativos. Los índices entre paréntesis marcan la relación de precios máximos entre esa figura y la vivienda de protección oficial de régimen general.
} 


\section{El "sistema público residencial". Los alojamientos dotacionales}

Resulta curioso observar cómo la garantía de acceso de los ciudadanos a la mayoría de los derechos sociales incorporados en la Constitución se ha estructurado sobre la base de articular un sistema público de prestación de servicios, paralelo o no a otro sistema privado. Así por ejemplo, el acceso ciudadano a la Sanidad, a la Educación o a la Seguridad Social.

La pregunta que acto seguido debemos responder entonces es la siguiente: ¿Podría ser considerada la Vivienda, más que como un bien patrimonial, como la prestación pública de un servicio al ciudadano? ¿Acaso la vivienda pública en alquiler no es sino la prestación pública de un servicio de alojamiento a colectivos necesitados? Y si eso es así, ¿qué consecuencias jurídicas a nivel urbanístico podríamos obtener? ¿Tiene sentido tratar a la vivienda pública en alquiler como un uso lucrativo o más bien tendría el carácter de una prestación social de tipo asistencial? ¿Es entonces la vivienda pública en alquiler un equipamiento?

En cualquier caso, la apuesta por un verdadero sistema público de alquiler pasa por dar una respuesta valiente y decidida a las preguntas arriba formuladas. El legislador vasco apuesta sin duda por este sistema público de alquiler sobre la base de institucionalizar la figura de los alojamientos dotacionales hasta el punto de hacerlos obligatorios en determinados municipios.

Con ello se podría decir que el legislador no sólo ha impuesto la existencia de coeficientes de usos lucrativos a través de la técnica de la calificación - separando por ejemplo el uso de la vivienda protegida y la vivienda libre -, como antes hemos visto. La opción legislativa también se extiende a entender que, debido a la nula rentabilidad económica y la obligación pública de la implantación del sistema de viviendas públicas en alquiler, el carácter lucrativo que tradicionalmente ha supuesto el uso residencial desaparece asimilando por tanto su régimen jurídico-urbanístico al propio de los equipamientos y las dotaciones públicas.

Consecuentemente con esta consideración los artículos 17, 81 y Disposición Adicional Novena de la Ley 2/2006 recogen esta figura de los alojamientos dotacionales. El artículo 17 aclara, en línea con lo expuesto para el artículo precedente, que las calificaciones de suelo que hagan los planeamientos urbanísticos para alojamientos tendrán el carácter de "equipamiento comunitario". La norma también prevé recalificar, previa autorización, suelos dotacionales preexistentes y sin uso previsible para el fin al que estaban previstos. La obtención de estos suelos, por su carácter dotacional, será por cesión obligatoria y gratuita a la administración pública responsable de la construcción y gestión del equipamiento, esto es, bien al Gobierno Vasco bien al propio Ayuntamiento correspondiente.

Así mismo, la calificación con este uso de alojamiento está sometida por ley a unos estándares mínimos obligatorios para determinados municipios ${ }^{39}$ - al igual que lo que ocurre para la vivienda protegida - pero también la calificación está sometida a unos estándares máximos para evitar el excesivo consumo de suelo dotacional con este uso.

Finalmente, la Disposición Adicional Novena de la Ley 2/2006 aclara la naturaleza jurídica de estos alojamientos dotacionales. De hecho, se dispone expresamente que los mismos deberán ser de titularidad pública, deben ser necesariamente puestos a disposición de la ciudadanía en

\footnotetext{
${ }^{39}$ El artículo 81 establece que los municipios con población igual o superior a 20.000 habitantes deben reservar en ámbitos residenciales $1,5 \mathrm{~m} 2$ de suelo por cada nueva vivienda prevista en el planeamiento y que, al menos, dé lugar a dos parcelas edificables e independientes.
} 
régimen de ocupación temporal y que tendrán carácter inalienable. La progresiva erección de este sistema público de alojamientos será objeto de concertación entre la administración local y autonómica.

Las primeras valoraciones que se pueden hacer de la institucionalización novedosa de esta figura son, a priori, positivas:

a. El sistema de implantación progresiva de los alojamientos dotacionales se basa en los principios de corresponsabilidad y de concertación entre el Gobierno Vasco y los Ayuntamientos.

b. Los alojamientos dotacionales supondrán en unos años la conformación de un auténtico sistema público de vivienda con vocación rotatoria y de puesta a disposición con carácter permanente en alquiler.

c. La flexibilidad en la localización de suelo para estos alojamientos - permitiendo incluso la recalificación de otros suelos dotacionales sin uso en los centros de los núcleos urbanos - evitarán que la implantación de los mismos se localice exclusivamente en los extrarradios de las ciudades evitando el fenómeno de la segregación socio-espacial. Por otra parte, contribuirán a generar mayor "tensión urbana" en barrios escasamente densos o barrios dormitorio pudiendo servir sus instalaciones en planta baja como "lugares de encuentro".

d. Su carácter público y equipamental permitirán la puesta en práctica de experiencias novedosas en materia de arquitectura y edificación - por ejemplo, programas de arquitectura bioclimática, instalación de sistemas domóticos, probatura de sistemas de mejora de eficiencia energética, acústica, etc. -.

La ordenación urbanística. Flexibilidad de la gestión de la documentación relativa a la ordenación urbanística.

\section{Introducción. La flexibilidad y la información pública}

Una de las principales demandas de los operadores urbanísticos ha sido la de demandar mayor flexibilidad en forma de reducción de tiempo que suele transcurrir entre la toma de la decisión pública de ordenación urbanística y la puesta en práctica de la misma por efecto de la complicada gestión administrativa que conlleva la alteración de las determinaciones de los planes urbanísticos.

A la vista de ello, se han introducido en la Ley 2/2006 diversos mecanismos de flexibilización de dicha documentación urbanística que van desde proponer una prevalencia de unas determinaciones de ordenación urbanística sobre otras, los cambios en los procedimientos de aprobación tanto de la formulación como de modificación de dichos planes hasta la mayor versatilidad y campo de acción de planeamiento pormenorizado respecto al planeamiento estructural. Todos estos aspectos se desarrollarán a continuación.

No obstante, conviene resaltar llegados a este punto que los mecanismos de flexibilidad en la gestión de la documentación urbanística deben ser compensados mediante un redoblamiento de los esfuerzos de los entes locales en mantener actualizada la 
documentación de los planes urbanísticos ${ }^{40}$. Ello es exigible en tanto no se quiera que el principio de información pública se resienta o, simplemente, se quiebre. En otras palabras, la posibilidad de alterar las determinaciones de un plan mediante otro instrumento diferente, como luego se verá, debe hacernos caer en la cuenta de la importancia de mantener actualizados los documentos de ordenación a los efectos de que tanto el propio Ayuntamiento como el ciudadano puedan disponer, de forma centralizada y en cualquier momento, de toda la información urbanística vigente en un determinado municipio y en un determinado momento.

\section{Separación entre ordenación estructural y ordenación pormenorizada}

Una de las principales novedades introducidas por la Ley $2 / 2006$, supone de hecho la terminación del principio tradicional de que las determinaciones de ordenación urbanísticas sólo pueden ser modificadas mediante la alteración del plan o instrumento urbanístico en las que las mismas estaban reflejadas.

Así, el artículo 58 de la Ley 2/2006, cuando aborda el tema del rango jerárquico de las determinaciones de ordenación, expresamente dispone que las de carácter estructural tendrán el rango propio de planeamiento general y las de carácter pormenorizado tendrán el carácter de planeamiento de desarrollo. Así, el legislador vasco opta por otorgar el rango jerárquico a las determinaciones de ordenación en función de su importancia, de su contenido y no de su forma, del plan en el que aparezcan las mismas recogidas. De esta forma, resulta posible alterar una determinación de Plan General mediante un planeamiento de desarrollo en tanto lo que se altera o modifica sea una determinación de carácter pormenorizado.

Consecuencia lógica de esta técnica es la necesidad de articular una separación entre las determinaciones de ordenación a las que la Ley da carácter estructural de aquellas a las que la Ley otorga carácter pormenorizado. Los artículos 53 y 56 disponen lo siguiente:

Ordenación estructural (artículo 53)

Estrategia de evolución urbana

Clasificación del suelo

Sectorización del suelo urbanizable

Calificación global

Fijación de plazos para desarrollo

Normas de protección medio ambiente

Red de sistemas generales y obtención

Reservas para vivienda protegida

Reservas para alojamientos dotacionales

Delimitación de ámbitos de ordenación

Fijación de edificabilidad urbanística

Uso característico y usos compatibles

Características básicas sistemas locales

Conexión con infraestructuras y redes

Delimitación de áreas de reservas PPS
Ordenación pormenorizada (artículo 56)

Red de sistemas locales

Delimitación de actuaciones integradas

Delimitación de actuaciones aisladas

Suelo urbano consolidado/no consolidado

Identificación actuaciones de dotación

Fijación de edificabilidades físicas

Fijación de usos pormenorizados

Coeficientes de ponderación entre usos

Elementos de construcción y edificación

Fijación de alineaciones y rasantes

Edificaciones fuera de ordenación

Criterios para la redacción de E. Detalle

Parcelación y régimen de la misma

Ajustes dentro de la parcela

Cualesquiera otras determinaciones

\footnotetext{
${ }^{40}$ A este fin de mantener permanentemente actualizada la documentación del planeamiento en aras a la información pública se dirigen las previsiones, por ejemplo, de los artículos 8, 52, 102, 103 y 107 de la Ley.
} 
Subclasificación del suelo no urbanizable Usos permitidos en suelo no urbanizable Delimitación de núcleos rurales Implantación dotaciones, infraestructuras

\section{Regulación de planes urbanísticos. Clases y contenidos}

También consecuentemente con esta separación operada, los planes urbanísticos resultan así mismo, clasificados en tres categorías diferentes en función del rango de determinación que recogen. Así, el artículo 59 presenta el siguiente esquema:

1. Planes de ordenación estructural. Son aquellos planes urbanísticos a los que se reserva el reflejo de las determinaciones de ordenación estructural pudiendo o no contener también determinaciones de ordenación pormenorizada. Estas últimas podrían ser modificadas por un planeamiento de ordenación pormenorizada.

Los planes de ordenación estructural recogidos en la Ley son los siguientes:

a) Plan General de Ordenación Urbana que tiene la ordenación estructural de todo el término municipal.

b) Plan de Compatibilización que regula la ordenación estructural de los ámbitos colindantes con otro municipio a los efectos de coordinar sus determinaciones.

c) Planes de Sectorización que tienen por objeto el establecimiento de la ordenación estructural de suelo urbanizable no sectorizado por el Plan General.

2. Planes de ordenación pormenorizada. Son aquellos planes urbanísticos que establecen la ordenación urbanística pormenorizada para el desarrollo de la ordenación estructural. Sus determinaciones pueden alterar la ordenación pormenorizada establecida en otros planes.

Los planes de ordenación pormenorizada que se recogen en la Ley son los siguientes:

a) Planes Parciales que ultiman la ordenación de los sectores cuando así se estableciera desde el Plan General o desde el Plan de Sectorización.

b) Planes Especiales de Ordenación Urbana que tienen por objeto la ultimación de la ordenación de las áreas en suelo urbano, cuando así lo estableciera el Plan General.

3. Otros Planes Especiales. Son aquellos que tienen objetos específicos, como implantaciones de dotaciones, equipamientos, infraestructuras, la rehabilitación y la regeneración urbana, la ordenación de determinados espacios o suelos, mejora o conservación del medio natural, etc. ${ }^{41}$ Estos planes pueden desarrollar las determinaciones de ordenación estructural del Plan General o bien tener carácter autónomo de los mismos. En todo caso, este tipo de planes en ningún caso pueden

\footnotetext{
${ }^{41}$ La Ley, en aras a la flexibilidad, deja abierto el objeto que dichos planes especiales pudieran abordar.
} 
alterar la ordenación estructural de los Planes Generales y, por lo tanto, tampoco la edificabilidad urbanística.

Por otra parte, conviene resaltar que la flexibilidad también es predicable en la Ley con relación al objeto y al ámbito de aplicación de determinados instrumentos de ordenación. Nos referimos concretamente a que el artículo 73, regulando los Estudios de Detalle, amplía su campo de acción a cualquier clase de suelo y no sólo al suelo urbano - incluyendo, por tanto, su aplicabilidad al supuesto del suelo urbanizable en fase desarrollo - y habilita a, dentro de unos límites, realizar ajustes de ultimación de la ordenación pormenorizada a través, por ejemplo, de la reordenación de los volúmenes. Esta reordenación puede alterar singularmente la calificación de suelo para la obtención de nuevos viales o nuevas dotaciones públicas. De este modo, los Estudios de Detalle amplían su objeto clásico como la fijación de alineaciones y rasantes a otros cometidos para dar respuesta a una práctica muy extendida en el mundo urbanístico.

Para finalizar este apartado sólo nos resta resaltar que la alteración competencial - y consecuentemente los cambios también en los procedimientos - en materia urbanística a favor de los Ayuntamientos contribuye decisivamente a la agilización de la gestión de la documentación y de los planes urbanísticos. No obstante, la profunda remodelación de los procedimientos de modificación y revisión de los planeamientos urbanísticos operada por la Ley, precisamente por su singularidad, será abordada en otro apartado.

El fenómeno de la sostenibilidad urbana. El principio del desarrollo sostenible adaptado a la legislación urbanística.

Introducción. El principio de desarrollo sostenible (artículo 3)

El concepto de desarrollo sostenible es esgrimido por muchas legislaciones urbanísticas como principios orientadores o incluso como límites en el ejercicio de la actividad urbanística. El artículo 3 de la Ley 2/2006, tras recoger una definición de dicho principio, en su párrafo tercero estructura las orientaciones que debe asumir la ordenación urbanística.

Estas orientaciones son las siguientes:

a. Sostenibilidad ambiental y equilibrio ecológico,

b. Protección de los recursos naturales del suelo,

c. La ocupación sostenible del suelo,

d. La rehabilitación y regeneración del patrimonio construido y edificado y,

e. La mixtificación de usos urbanos en aras a propiciar la reducción de la movilidad forzada en nuestros pueblos y ciudades.

Estas ideas se irán desgranando progresivamente a través de la relación de cada concepto con medidas legales concretas para su práctica.

Sostenibilidad ambiental y equilibrio ecológico 
Bajo este epígrafe vamos a hacer un breve repaso a las concretas medidas que desde la Ley 2/2006 se prescriben en base a la relación entre la ordenación urbanística y las consideraciones de sostenibilidad ambiental.

Así, es significativo que el artículo 55, en desarrollo del concepto de "estrategia de evolución urbana", obligue a la ordenación estructural a la determinación de la secuencia lógica del desarrollo urbanístico mediante el preceptivo preestablecimiento de condiciones objetivas que aseguren la asunción de la nueva urbanización en la trama urbana preexistente. Por otra parte, también en este artículo se exige a la ordenación estructural a delimitar tanto los núcleos históricos a efectos de su rehabilitación y conservación así como los ámbitos degradados a los efectos de rehabilitación o regeneración.

Muy relacionado con esta idea de la coherencia de la evolución urbana, debemos destacar que el artículo 62, y en relación con la documentación preceptiva en todos los Planes Generales, se prescribe tanto la presentación de una memoria justificativa del cumplimiento del informe preliminar de impacto ambiental como del estudio realizado desde la consideración de "la capacidad de acogida" ${ }^{42}$ de dichos suelos naturales para el cumplimiento de las previsiones contenidas en el Plan. Este control de sostenibilidad resulta reforzado en los Planes de Sectorización - artículo 65 de la ley - para los que se requiere además compromisos concretos que garanticen el respeto de la estrategia municipal de sostenibilidad adoptada en el Plan General.

Finalmente, destacamos que se dedica un artículo específico, artículo 72 , al desarrollo de una clase de plan especial concreta a la que el legislador ha querido dar cobertura específica. Es el caso del plan especial de protección y conservación que tiene por objeto tanto elementos naturales como artificiales y que pueden versar sobre el litoral, el paisaje, el medio urbano, el medio rural, edificaciones, instalaciones, explotaciones agrarias, espacios forestales, ecosistemas fluviales, así como cualquier otro elemento.

\section{Protección de los recursos naturales del suelo. Régimen del suelo no urbanizable}

Sin ánimo de ser exhaustivos, al superar sobradamente el objeto del presente trabajo, haremos una reseña de los aspectos más importantes en materia del régimen jurídico de protección del suelo no urbanizable que incorpora la Ley 2/2006.

Antes que nada debemos recordar que la Ley 6/1998 de Suelo y Valoraciones, por aplicación de su estrategia de liberalización, limita en gran medida la capacidad de los legisladores urbanísticos autonómicos para la clasificación de suelo en la categoría de no urbanizable. Uno de las consecuencias principales se traduce en la obligación que tienen los legisladores urbanísticos de disponer que la clase de suelo urbanizable es la residual. En otras palabras, el legislador estatal impone que la clasificación del suelo como urbano y como no urbanizable debe estar justificada en situaciones objetivas vedando la apreciación subjetiva del planificador urbanístico en la consideración de estos suelos ${ }^{43}$.

\footnotetext{
${ }^{42}$ Especialmente de interés resulta esta previsión si se toma en consideración que el proyecto de ley de suelo aprobado recientemente por el Consejo de Ministros prevé la exigibilidad en su artículo 15 de un mapa de riesgos naturales y un informe específico sobre la suficiencia de los recursos hídricos.

${ }^{43}$ Véanse los artículos 9 y 10 de la Ley 6/1998 de Suelo y Valoraciones. Con posterioridad, tras la Sentencia del Tribunal Constitucional 164/2001, el legislador estatal en la Ley 10/2003 tuvo que reconocer el valor de la apreciación subjetiva del planificador urbanístico como un criterio de clasificación del suelo como no urbanizable. No obstante, el suelo urbanizable perduró como la categoría residual frente al suelo urbano y no urbanizable.
} 
Por el contrario, la estrategia del desarrollo sostenible y, por lo tanto, la preservación del suelo en su estado natural coexistiendo con los desarrollos urbanos de manera razonable era una de las apuestas más claras del legislador vasco. Por ello, la Ley 2/2006 ha optado por respetar el carácter residual del suelo urbanizable - artículo 14.1.b) - precediendo el suelo no urbanizable de una definición amplia de modo que el planificador pueda plasmar en los planes y previsiones urbanísticas la estrategia de desarrollo sostenible que tenga acordada el municipio ${ }^{44}$.

Los artículos 28 y siguientes establecen un régimen de usos en el suelo no urbanizable más estricto que el que existía con carácter precedente. Destacaríamos en esta línea la prohibición de reclasificar en 20 años el suelo forestal que hubiere perdido sus valores por causa de fuerza mayor - incendio, daño medioambiental o tala ilegal -, previsión que anteriormente no existía.

Así mismo, esta regulación se complementa con otras previsiones legales - artículo 28 - que limitan en gran medida la utilización de dichos suelos para usos ajenos a su lógico aprovechamiento natural limitando sus usos a los expresamente recogidos en las Directrices de Ordenación del Territorio. También en este artículo se establecen condiciones más estrictas para las construcciones que se pretendan erigir en dichos suelos evitando, por una parte, el riesgo de formación de núcleos de población y, por otra, los daños ecológicos, funcionales o simplemente paisajísticos que las mismas podrían conllevar.

También se debe reseñar el régimen jurídico más estricto que el precedente ${ }^{45}$ para evitar la abusiva práctica de implantación de uso residencial en los suelos clasificados como no urbanizables. Así, el régimen jurídico de los núcleos rurales - artículo 29 -, la nueva regulación sobre las licencias de reconstrucción de caseríos - artículo 30 - y de construcción de viviendas ligadas a explotación en el sector primario - artículo 31 -.

\section{La ocupación sostenible del suelo. Los estándares de edificabilidad}

Uno de los objetivos y compromisos que el Programa Marco Ambiental de la Comunidad Autónoma del País Vasco 2002 - 2006 ha destacado consiste en evitar los desarrollos urbanísticos en baja densidad introduciendo densidades edificatorias más altas en las zonas aptas para ello dentro del marco de las Directrices de Ordenación del Territorio ${ }^{46}$. Se parte del hecho de que el suelo es un recurso natural de carácter no renovable de modo que se procura hacer compatible los desarrollos urbanísticos con la preservación del suelo natural en su estado original. Tampoco hay que ignorar que los desarrollos urbanísticos en baja densidad, a parte de consumo de suelo, generan la necesidad artificial de movilidad, mayoritariamente en vehículo motorizado privado, por lo que la ineficiencia de este tipo de modelo de desarrollo es evidente.

Por otra parte, no podemos pasar por alto que la CAPV tiene grandes limitaciones en la disponibilidad de suelo apto para practicar los desarrollos urbanísticos así como que el consumo del territorio en base al uso residencial en baja densidad no es el más apto para la

\footnotetext{
${ }^{44}$ De esta forma, el artículo 13 separa para la clasificación del suelo como no urbanizable los supuestos de "improcedencia" e "inadecuación" incluyendo en esta última categoría el supuesto de garantizar "el respeto a la estrategia local de sostenibilidad del modelo de desarrollo urbanístico".

${ }^{45}$ Dicho régimen jurídico precedente radica en la ya analizada Ley 5/1998 de Medidas Urgentes sobre el régimen de los núcleos rurales y viviendas ligadas a explotación agropecuaria.

${ }^{46}$ La referencia concreta es el compromiso señalado como M2C03. "Programa Marco Ambiental de la Comunidad Autónoma del País Vasco. Estrategia Ambiental Vasca de Desarrollo Sostenible 2002 - 2020". Departamento de Ordenación del Territorio y Medio Ambiente. IHOBE. 2002.
} 
construcción de viviendas protegidas. Todo esto convierte en lógico que una legislación urbanística extienda la técnica de los estándares urbanísticos para exigir en los futuros desarrollos una densidad mínima. De hecho, en el informe de seguimiento del cumplimiento de los objetivos de dicho Programa el indicador de superficie de suelo "artificializada" tenía una evolución muy desfavorable.

Así, con carácter novedoso, el artículo 77 en sus párrafos 4 y 5 establece con carácter obligatorio el cumplimiento de un estándar mínimo de relación entre la edificabilidad urbanística y la superficie del territorio a ocupar. De este modo, con carácter general en ámbitos residenciales de suelo urbano y urbanizable no podrán ser admisibles relaciones inferiores a $0,4 \mathrm{~m} 2$ de techo por cada $\mathrm{m} 2$ de suelo en municipios obligados a reservar vivienda protegida. En los municipios no obligados a reservar suelo para vivienda protegida este estándar queda fijado en 0,25 m2 de techo por cada $\mathrm{m} 2$ de suelo. En ámbitos no residenciales - uso industrial o terciario - se establece que la edificación deberá ocupar al menos el $30 \%$ de la superficie de suelo $^{47}$.

En esta misma línea también debemos llamar la atención sobre que los estándares máximos de densidad también han sido revisados al alza en una clara intención de permitir mayor y mejor aprovechamiento del escaso suelo apto para desarrollos urbanísticos. El límite tradicional de 75 viviendas por hectárea es entonces sustituido por los índices de 1,3 ó 1,1 m2 de techo por cada m2 de suelo, según los municipios de que se trate.

Mixtificación de usos urbanos. La reducción de la necesidad artificial de movilidad. Estándares de dotaciones.

Una de las principales críticas por parte del mundo municipal de la que fue objeto el proyecto de ley de suelo y urbanismo aprobado por el Gobierno Vasco es que el establecimiento de estándares máximos y mínimos de edificabilidad urbanística suponía la apuesta del legislador por un tipo o por un modelo de desarrollo urbano muy concreto, todo ello en detrimento de su legítima autonomía municipal. Y es que finalmente el ya citado artículo 77 , como ya se ha dicho, establece límites máximos y mínimos de edificabilidad en suelos urbanos y urbanizables.

Por otra parte, la estandarización que exige el cumplimiento de parte de la edificabilidad residencial en forma de vivienda protegida también supone un límite al diseño urbano si tenemos en cuenta que dicho uso de vivienda protegida no es razonable implementarlo sobre la base de la media ni, sobre todo, de la baja densidad.

La baja densidad se ha convertido de un tiempo a esta parte en el factor más relevante de ineficiencia en materia de movilidad urbana. La extensión irrazonable de la ciudad en el territorio, mediante una no menos ilógica relación entre el número de habitantes y superficie ocupada por estos, además de elevar de forma exponencial el coste del mantenimiento ordinario de la ciudad - recorridos más extensos para el transporte público y recogida de basuras, incremento espectacular de las zonas ajardinadas y de la superficie de vialidad a mantener, etc. -, supone la generación de necesidad de movilidad a través del vehículo privado por las distancias que se provocan entre el lugar de residencia y la localización de las dotaciones públicas y las infraestructuras.

47 El régimen de transitoriedad establecido en la Ley 2/2006 además convierte estos estándares mínimos en obligatorios con carácter automático a la entrada en vigor de la ley para todo suelo que no disponga de la ordenación pormenorizada aprobada definitivamente. 
La Ley 2/2006 también introduce, como viene siendo tradicional, la exigencia de unos estándares mínimos de reserva de terrenos para sistemas generales - artículo 78 - y para sistemas locales - artículo 79 -, aunque remite su la fijación de su determinación concreta a reglamento. A este respecto resulta conveniente resaltar dos reflexiones que fueron consideradas a la hora de abordar el texto legal: Primero, la desaparición del número de viviendas y sustitución por la relación entre los $\mathrm{m} 2$ de techo y suelo como referencia para la estandarización de dotaciones y, segundo, la consideración estática y dinámica de la superficie destinada a dotaciones públicas a lo largo de la vigencia del planeamiento respectivo.

Respecto al primer aspecto, no se puede perder de vista que el índice de ocupación media de personas en cada vivienda, en el Estado español ha descendido de forma muy acusada tendiendo a buscar la equiparación con la media europea ${ }^{48}$. Por lo tanto, cada vez se necesitan más viviendas pero de menor superficie ya que las mismas van a estar ocupadas por unidades convivenciales de una o, a lo sumo, dos personas. En el plano urbanístico se impone entonces la pregunta sobre si la estandarización de superficies de dotaciones públicas tiene sentido referirla al número de viviendas - lo que llevaría inevitablemente al cada vez menor uso de dichas dotaciones - o a la edificabilidad prevista. El legislador vasco opta por esta segunda opción.

En lo referente a la presencia de dotaciones públicas en cada ámbito de planeamiento y su relación con la exigible mixtificación de usos debemos referirnos al artículo 79.5 de la Ley 2/2006 cuando prohíbe toda dispensa, minoración o transferencia de los estándares de dotaciones locales establecidos legalmente. En lo que refiere a su consideración dinámica, destacamos la importancia del artículo 105 y especialmente de los límites para las modificaciones de planes ya que en su párrafo sexto intentan evitar la alteración de forma sustancial de la relación entre la edificabilidad y la superficie dotacional preexistente. Bajo esta premisa cabe también interpretar el artículo 83 que exige a todos los suelos urbanizables mantener los estándares propios de esta clase de suelo aunque el mismo haya devenido en urbano por ejecución del planeamiento.

Todos estos condicionantes expuestos buscan provocar la obligatoria densificación de nuestros pueblos y ciudades y la mixtificación de los diferentes usos urbanos. La cada vez mayor demanda ciudadana de "calidad urbana" parece pasar no sólo por la prestación de los servicios urbanísticos sino por un concepto más amplio de "derecho a la ciudad". A ello va orientado la extensión de los estándares máximos de edificabilidad, técnica aplicada respecto al suelo urbanizable, también al suelo urbano en el ya citado artículo 77 .

\section{La regeneración y la rehabilitación del patrimonio construido y edificado}

La Comunidad Autónoma del País Vasco ha estado sometida a una fuerte presión de crecimiento urbano en su etapa de industrialización. Este crecimiento poblacional ha tenido especial incidencia en aquellos núcleos urbanos que eran soporte de dichas actividades industriales, y de forma particular a lo largo de la franja litoral.

El asentamiento de las diferentes actividades urbanas se hizo con escaso control de los usos del suelo y de las calidades constructivas y de urbanización de dichos barrios. De este modo, la morfología urbana resultante tuvo como resultado la yuxtaposición de usos incompatibles

\footnotetext{
${ }^{48}$ Así, el índice actual se sitúa en 2,7 personas por hogar cuando hace unos diez años este índice se situaba en España por encima del 3.
} 
desde el punto de vista funcional y ambiental, elevadas densidades, contaminación y congestión de las infraestructuras al servicio de la industria ${ }^{49}$. La singularidad territorial del País Vasco, especialmente en lo que hace referencia a la vertiente cantábrica y la escasez de suelo apto para el emplazamiento de dichos asentamientos urbanos han sido dos de los factores fundamentales que han provocado históricamente la pugna de los diversos usos por ubicarse en los reducidos emplazamientos disponibles.

En esa tesitura, la profunda transformación de la base económica fundamental de la Comunidad Autónoma desde el sector secundario - fenómeno de desindustrialización - hacia el sector terciario, tiene que venir necesariamente acompañada de una profunda revisión de las exigencias de ubicación y de calidad ambiental del aparato productivo vasco y la consiguiente adaptación del medio urbano y territorial.

La entidad de los problemas de deterioro urbano exige centrar todos los esfuerzos públicos y privados en torno al reto colectivo de la renovación urbana, especialmente en Cascos Históricos y Áreas Degradadas, en aras a la consecución de los objetivos de fomento de la mejora de la calidad residencial y ambiental de nuestros núcleos urbanos, la reubicación del tejido productivo y la readaptación de los espacios urbanos hacia el sector económico terciario y de ocio. Esta ha sido la tradicional orientación de las políticas de fomento de vivienda que han discriminado positivamente la adquisición y rehabilitación de vivienda en estas zonas necesitadas de mayor atención pública.

No obstante, el desarrollo de inversiones públicas en estas áreas y entornos urbanos necesitados de especial atención, requiere dotar a las Administraciones Públicas competentes de las herramientas de intervención de la acción urbanística suficientes a los efectos de la obtención de óptimos resultados de dichas intervenciones. Ante esta situación, la Ley 2/2006 incorpora una serie de herramientas de gestión urbanística de carácter público y otras medidas de intervención administrativa en manos de las Administraciones Públicas. Entre ellas, merecen ser destacadas por su novedad las siguientes:

a. La exigencia legal de realización de Inspecciones Técnicas para aquellos edificios de antigüedad superior a 50 años - artículo 200 -.

b. Posibilidad de delimitar por el planeamiento urbanístico áreas sometidas a los derechos de tanteo y retracto no solamente referidas a zonas de futura expansión de la ciudad sino también referidas a áreas urbanas que hayan de estar sometidas a operaciones integrales de reforma o rehabilitación urbana - artículo 125 -.

c. Ampliación de las posibilidades de actuación mediante Planes Especiales, especialmente en intervenciones públicas de reforma mediante Planes Especiales de Renovación Urbana - artículo 71 - y a través de operar con flexibilidad la posibilidad de delimitación de unidades de ejecución en suelo urbano - artículo 145 -.

d. Habilitación de la legitimación expropiatoria de vivienda vacía sobre la base del incumplimiento de la función social de la propiedad y referido especialmente a áreas de

\footnotetext{
${ }^{49}$ No podemos olvidar que estos núcleos industrializados con un ambiente urbano de baja calidad se han ido históricamente asentando en el fondo de los valles para el aprovechamiento, por un lado de los canales de por los que discurre la infraestructura viaria fundamental $y$, por otro, por la posibilidad de saneamiento que provocaban los cauces fluviales.
} 
reforma interior o áreas que estén sometidas a operaciones de regeneración urbanística, todo ello para operar con mayor facilidad desde las Administración Pública dichas actuaciones - artículo 177.e)-

e. Regulación novedosa de las tradicionales "órdenes de ejecución" a favor de dotar de más y mejores instrumentos a las administraciones públicas para asegurar su cumplimiento - artículo 203 -.

La ejecución de la ordenación urbanística. El concepto de la programación de la obra pública urbanizadora. Los sistemas de ejecución "privados". Obligación de edificación y de rehabilitación.

Quizás sea este uno de los aspectos más importantes en el que se termina jugando la credibilidad del Urbanismo. De nada sirve la fijación de una determinada ordenación urbanística si la misma no se termina llevando a la práctica. Según la percepción ciudadana, la ejecución de los desarrollos urbanísticos es lenta y siempre queda al albur de los intereses económicos en juego. Así mismo, la Asociación de Municipios Vascos se ha manifestado en el mismo sentido reclamando más instrumentos y formas de ejecución que los tradicionales.

\section{Los Programas de Actuación Urbanizadora.}

La actividad de ejecución tiene que empezar a leerse por la ordenación urbanística. No puede conceptuarse la actividad de ejecución como un asunto propiamente privado y sólo excepcionalmente público. El interés público que recorre la actividad de ordenación tiene que extenderse también a la actividad de ejecución, con carácter independiente del sistema de ejecución público o privado elegido. Esta es la idea que preside los Programas de Actuación.

Este argumento formó parte de la reflexión del legislador valenciano en 1994. Este se atrevió a extender el régimen jurídico del suelo urbanizable no programado que ya existía en el Texto Refundido de 1976 a todas las actuaciones sistemáticas o integradas en cualquier clase de suelo, urbano o urbanizable. Principalmente, extendió la posibilidad, que convirtió en obligación, de llamar a un tercero para ordenar un ámbito y encargarse de su íntegra ejecución - el agente urbanizador - sometido a una serie de condiciones y plazos. Con ello el legislador valenciano rompía el "monopolio" del propietario privado del suelo en el acto de planificación y ejecución introduciendo el principio de libre competencia. Ello se justifica plenamente sobre la base de considerar el interés público existente en los actos de planificación y ejecución urbanísticos.

El legislador vasco parte también de esa idea pero el sistema dibujado del régimen de los Programas de Actuación Urbanizadora termina siendo diferente. Si bien adopta y refuerza la idea del legislador valenciano de someter la actividad de ejecución a determinadas condiciones y plazos se cuida al mismo tiempo de aclarar que la ordenación urbanística no forma parte del contenido de los Programas de Actuación Urbanizadora. De esta forma, los Programas de Actuación en la legislación valenciana se conceptúan como instrumentos de ordenación y en la Ley 2/2006 se configuran como puros instrumentos de ejecución. Las principales diferencias entre ambas instituciones son las siguientes: 


\begin{tabular}{|l|l|l|}
\hline & Programa Act. Integrada & Programa Act. Urbanizadora \\
\hline Naturaleza Jurídica & Instrumentos Ordenación & Instrumentos Ejecución \\
\hline Sistema de ejecución privada & Agente Urbanizador & $\begin{array}{l}\text { Agente Urbanizador } \\
\text { Concertación directa }\end{array}$ \\
\hline Aprobación del Programa & Acto de adjudicación & Previa a la adjudicación \\
\hline Establece la ordenación & $\mathrm{SI}$ & $\mathrm{NO}$ \\
\hline $\begin{array}{l}\text { Establece condiciones } \\
\text { ejecución }\end{array}$ & $\mathrm{SI}$ & $\mathrm{SI}$ \\
\hline $\begin{array}{l}\text { Adjudica actividad de } \\
\text { ejecución }\end{array}$ & $\mathrm{SI}$ & $\mathrm{SI}$ \\
\hline Adjudica la obra urbanizadora & $\mathrm{SI}$ & Optativo \\
\hline
\end{tabular}

La diferenciación respecto de los Programas de Actuación Integrada de la legislación valenciana es clara. Así como en aquellos el objeto del programa supone una alternativa mixta de ordenación y ejecución, en los programas de la Ley 2/2006 el objeto de los mismos se circunscribe a la actividad de ejecución. De ahí la naturaleza jurídica distinta que a dichos programas reconoce la legislación.

Por otra parte, en la legislación valenciana se prevé que la adjudicación del programa supone la aprobación definitiva del mismo mientras en la legislación vasca el programa se debe aprobar con carácter previo, quedando fijadas definitivamente las cargas que son imputables a los propietarios. Por ello, en el supuesto de optar por la vía del agente urbanizador, la aprobación definitiva del programa supone el inicio del procedimiento de selección de agentes urbanizadores mediante el correspondiente concurso público - artículos 166 y siguientes -.

Por otra parte, la adjudicación de la ejecución de un Programa de Actuación Urbanizadora no tiene por qué confundirse con la adjudicación de la ejecución misma de la obra urbanizadora. En el artículo 172 de la ley se deja entrever que es posible que la ejecución de la obra urbanizadora forme parte o no del objeto del Programa pudiendo adjudicarse la ejecución de la obra y del programa simultáneamente o ser aquella posterior a esta.

Por lo tanto, parece claro que la Ley 2/2006 ha circunscrito la virtualidad jurídica de los Programas exclusivamente a la fijación de las condiciones y plazos en el que se tiene que desarrollar la actividad de ejecución. La "ejecución en plazo" es una idea que recurrentemente aparece en el texto legal. Así, se debe resaltar que la ley maneja en su artículo 50 la idea de la ordenación urbanística como organización del espacio pero también como la organización de las determinaciones temporales de la ejecución. Y consecuentemente, el artículo 53.1.d de la Ley 2/2006 establece como una determinación de la ordenación urbanística estructural la fijación de los plazos para la elaboración y aprobación del planeamiento de desarrollo y de los programas de actuación urbanizadora ${ }^{50}$. Aunque es un aspecto que no es del todo novedoso respecto a nuestra legislación precedente, sí parece importante resaltar la centralidad que el legislador ha querido otorgar a este aspecto determinando con carácter obligatorio y ya desde el planeamiento estructural las reglas de juego temporales para proceder a la ejecución de la ordenación urbanística.

\footnotetext{
${ }^{50}$ Sobre la dimensión temporal de la ejecución urbanística, ver el artículo 133 de la Ley
} 
Entrando propiamente en la figura de los Programas, el artículo 152 conceptúa expresamente los Programas de Actuación Urbanizadora y extiende su objeto la organización de la actividad de ejecución tanto en lo que refiere a las características básicas como a la organización de los tiempos en actuaciones integradas - que pueden coincidir total o parcialmente con ámbitos de ordenación concretos siempre que afecte a unidades de ejecución completas ${ }^{51}$-. Por resumir, se podría decir que el contenido de los Programas consiste en determinar el dónde, qué, quién, cómo y cuándo de la realización de estas actuaciones. Estas serán las condiciones que debe fijar y garantizar su cumplimiento la administración pública con carácter previo a la actividad de ejecución en las actuaciones integradas.

En ese sentido, los Programas tienen por objeto las actuaciones integradas en suelo urbano no consolidado y urbanizable sectorizado estableciendo dichos programas los siguientes parámetros:

a. La delimitación de la o las unidades de ejecución que constituyen su objeto.

b. El régimen de ejecución - público o privado - así como la fijación del concreto sistema de actuación.

c. Las determinaciones jurídicas, técnicas y económicas de ejecución y, en todo caso, la regulación de sus contenidos mínimos.

d. La fijación de la totalidad de las obras de urbanización a realizar y de las cargas a levantar así como la estimación aproximada de su coste.

e. El programa temporal de ejecución de las obras de urbanización y, en su caso, de edificación.

f. En el supuesto en el sistema de actuación del Programa sea el de agente urbanizador, las bases orientativas para la selección del agente urbanizador mediante la futura convocatoria de concurso público.

Como se observa, los Programas de Actuación Urbanizadora en ningún caso pueden alterar la ordenación estructural ni la ordenación pormenorizada determinada en el planeamiento correspondiente más allá de lo que constituye específicamente su objeto. Por ello, la aprobación de los Programas deberá ser siempre posterior o simultánea al plan urbanístico que legitima la ejecución, plan que contendrá todas las determinaciones urbanísticas propias de la ordenación estructural y pormenorizada y que legitiman su ejecución pero anterior al desarrollo de las respectivas actuaciones. Es importante señalar que los Programas de Actuación Urbanizadora pueden simultanear su tramitación y aprobación definitiva con arreglo a la tramitación de aquellos planes de ordenación estructural o pormenorizada de los que traen causa - Planes Generales, Planes de Sectorización, Planes Especiales de Ordenación Urbana y Planes Parciales - con el objeto de no dilatar los tiempos de su tramitación y por tanto de la ejecución.

Obra pública urbanizadora. Sistemas de ejecución "privados"

\footnotetext{
${ }^{51}$ Con esta previsión el legislador separa completamente el concepto de los ámbitos de ordenación urbanística y de los ámbitos de ejecución. Resulta posible que la ordenación defina una actuación integrada que agrupe varias unidades de ejecución pertenecientes a áreas o sectores diferentes por la conveniencia de dar unicidad a la ejecución de la obra urbanizadora.
} 
Aunque la Ley 2/2006 no lo reconozca expresamente, lo cierto es que se asume que la obra urbanizadora tanto de sistemas locales como de generales es una obra pública ${ }^{52}$ tanto si desarrollan en régimen de obra pública ordinaria como si son consecuencia de la realización de una actuación integrada. La primera consecuencia es que la ejecución de la obra urbanizadora no debe quedar exclusivamente en manos de los propietarios privados ni en cuanto contenidos ni en cuanto a los tiempos de su ejecución, quedando dichas condiciones fijadas y garantizadas por la administración pública bien en el acto de aprobación del correspondiente programa de actuación urbanizadora - actuaciones integradas - bien en el propio acto de aprobación del proyecto de obra pública ordinaria - actuaciones de ejecuciones de dotaciones públicas -

Centrándonos en las actuaciones integradas, que ya hemos apuntado que se declaran de responsabilidad pública, el artículo 141 permite que los regímenes de ejecución de estas actuaciones puedan ser tanto privados como públicos. La ejecución en "régimen privado" consistirá entonces en encargar a un particular la realización y garantía de cumplimiento de las condiciones establecidas y aprobadas en el correspondiente programa ${ }^{53}$.

El legislador valenciano siempre adjudica dicho encargo a un privado por la vía concurrencial ya que, como se ha dicho, la ejecución de la obra urbanizadora forma parte de la adjudicación. Por el contrario, el legislador vasco deja la opción abierta a que la adjudicación de la realización del programa pueda o no incluir en su objeto la ejecución de la propia obra urbanizadora. De esta forma, se salva la posibilidad de la adjudicación directa de un programa directamente a los propietarios privados mediante convenio con el Ayuntamiento, ello condicionado a que la ejecución de la propia obra urbanizadora se saque por parte de los propietarios - junta de concertación - y, a su costa, a concurso con sujeción a la legislación de contratación pública. De esta forma, en el régimen de ejecución privado de actuaciones integradas cohabitan las figuras de agente urbanizador y de la junta de concertación configurándose como dos sistemas diferenciados. Gráficamente,

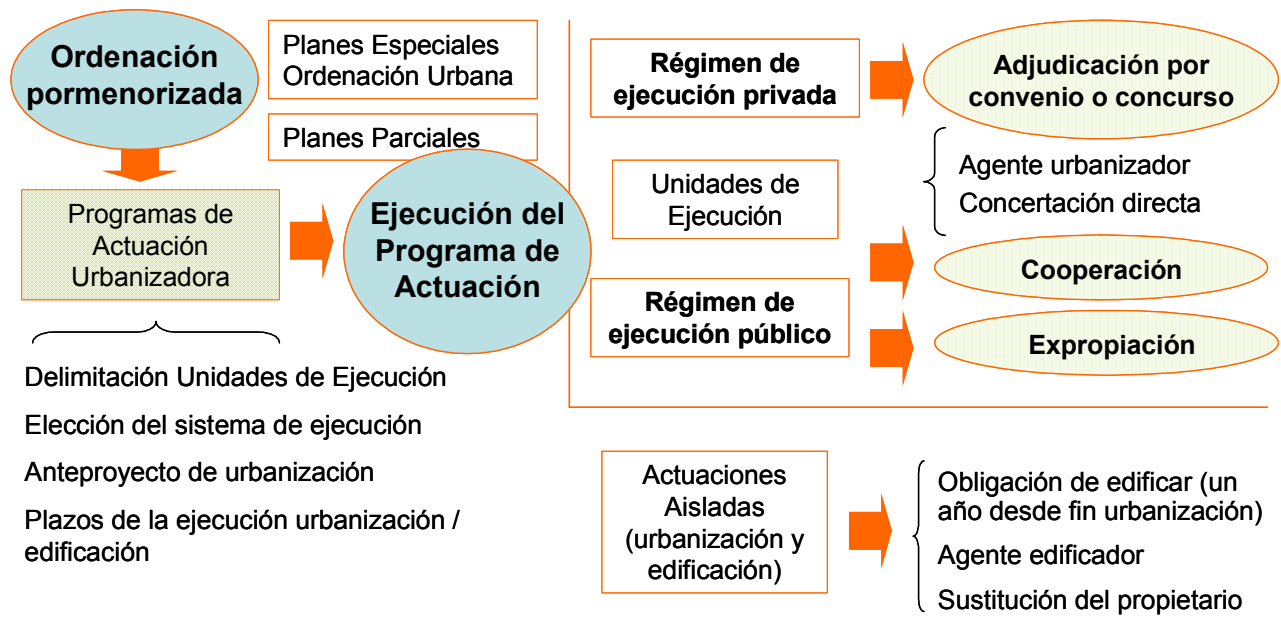

Fuente: Elaboración propia

\footnotetext{
${ }^{52}$ Concretamente, consultar párrafos segundo y tercero del artículo 140 de la ley.

${ }^{53}$ El artículo 159.2 de la Ley 2/2006 conceptúa el encargo a un privado de la ejecución de una actuación integrada como una "concesión administrativa"
} 
Por lo tanto, la adjudicación a un privado de la ejecución de un programa de actuación urbanizadora no tiene por qué llevar aparejada la ejecución material de la obra urbanizadora. Esta obra urbanizadora podrá ser adjudicada y llevada a cabo, bien bajo la responsabilidad de un tercero - agente urbanizador - o de los propietarios de suelo - sistema de concertación con posterioridad a la adjudicación del programa, todo ello con sujeción a los requisitos exigidos por la contratación pública.

De esta forma, pudiendo separar del objeto del programa de actuación urbanizadora la ejecución de la propia obra urbanizadora y difiriendo la misma a otro momento posterior, se hace compatible el concepto de la obra urbanizadora como obra pública con la adjudicación directa, mediante convenio, de la ejecución de un programa a una junta de propietarios. Lógicamente, una vez firmado el convenio con la administración para la realización del correspondiente programa, la junta de propietarios deberá adjudicar posteriormente la realización material de la obra mediante la convocatoria del correspondiente concurso con sujeción a la legislación de contratación pública. Entonces, el objeto del programa quedaría en este caso circunscrito a la propia gestión de la actividad de ejecución - realización de la equidistribución de beneficios y cargas, redacción de los proyectos técnicos, convocatoria del concurso para la materialización de las obras de urbanización así como la financiación de las mismas a su costa -, todo ello con sujeción a los contenidos y los plazos previstos en el propio programa y suficientemente avalado para asegurar su cumplimiento.

Otra de las consecuencias de la consideración de la obra urbanizadora como una obra pública es el establecimiento legal de un protocolo para asegurar el correcto traspaso de la responsabilidad de su titularidad, de su conservación y de su obligación de mantenimiento a la administración pública cuando su ejecución ha sido encargada a un privado - artículo 198 -. En esta misma línea se enmarcan las limitaciones impuestas por el artículo 197 a la institución de las juntas de conservación, en las que el deber de conservación es impuesto a los propietarios, cuya existencia se condiciona a su previa justificación y al señalamiento preceptivo de la temporalidad que marque la cesación de dicha obligación jurídica.

En el reforzamiento de la idea del interés público existente en la ejecución de las actuaciones urbanísticas en plazo, destacar que el artículo 159, en el supuesto de que el sistema de ejecución privado viniera fijado por el planeamiento, establece el periodo de dos años para presentar propuesta de programa de actuación a los sujetos privados so pena de pasar a un sistema público de ejecución. Si el sistema preestablecido por el planeamiento fuera el de la concertación directa, la no presentación de convenio regulador en el plazo de seis meses por parte del $50 \%$ de la propiedad del suelo, supondrá automáticamente el paso al sistema de agente urbanizador para su selección por concurso - artículo 160.3 -.

\section{Obligación de edificación y rehabilitación}

Aunque el ya citado artículo 140 en su párrafo primero ya declara las actuaciones aisladas entendiendo por tales las estrictamente edificatorias - responsabilidad de los propietarios de las respectivas parcelas o solares, prosigue advirtiendo que la actividad de edificación está sometida a intervención administrativa.

El artículo 189 de la ley establece, en el marco de la citada facultad de intervención y siguiendo la filosofía descrita anteriormente para las actuaciones integradas, una obligación genérica de edificación en plazo. Así, existe una obligación genérica legal de edificar en el plazo máximo de un año desde la finalización de las obras de urbanización, salvo que el programa de actuación 
urbanizadora - que también puede imponer plazos perentorios de edificación - señale unos plazos inferiores. Una vez transcurrido dicho plazo sin procederse a darse inicio a la edificación, se debe incoar un procedimiento, con audiencia del propietario del mismo, por el que se declara administrativamente la parcela o solar en situación de "edificación forzosa". Esta declaración supone cualquiera de las siguientes consecuencias ${ }^{54}$ :

1. El Ayuntamiento convoca un concurso para llamar a terceros interesados en proceder a la edificación, previa expropiación de la parcela o solar a cuenta del agente edificador - artículo 190 -.

2. El Ayuntamiento procede, por cuenta del propietario incumplidor, a la venta forzosa de la parcela o solar mediante procedimiento de concurso - artículo 191 -.

3. El Ayuntamiento procede a la expropiación forzosa de la citada parcela o solar así declarados - artículo 193 -.

Así mismo y de forma paralela, los artículos 199 y siguientes, parten de la obligación legal genérica de conservación y rehabilitación de inmuebles ${ }^{55}$. Como parte de esta obligación, y con carácter novedoso, el artículo 200 establece la obligación genérica de proceder, por cuenta de la propiedad, a someter a los edificios de antigüedad superior a 50 años y a todos los edificios catalogados o protegidos a una inspección técnica periódica. Dicha periodicidad queda fijada en el plazo de diez años. Tal como ya ha avanzado el Departamento de Vivienda y Asuntos Sociales, el cumplimiento de esta obligación, será requisito imprescindible para la obtención de las ayudas públicas que, desde el Gobierno vasco, financian la actividad de rehabilitación.

En el caso de incumplimiento de dicho deber de conservación y mantenimiento, la ley establece la obligación de las administraciones públicas del dictado de órdenes de ejecución cuyo incumplimiento por parte del propietario puede dar lugar bien a la ejecución subsidiaria de la administración por cuenta del obligado, bien a la imposición por aquella al incumplidor de multas coercitivas, o bien a la expropiación forzosa del inmueble. En situaciones de deficiencias estructurales con peligro de ruina física, se habilita al llamamiento a un tercero para proceder a la rehabilitación integral del inmueble a costa del incumplidor - artículo 203 -.

\footnotetext{
${ }^{54}$ La posible entrada en vigor del proyecto de ley de suelo estatal alterará el panorama descrito en esta materia dotando a las administraciones públicas de mejores herramientas. Entre ellas merece la pena destacar la figura de la "sustitución forzosa" que permite construir la edificación sobre fundo ajeno con una minusvaloración del mismo de hasta un $50 \%$ de su valor.

${ }^{55}$ En la fase de tramitación parlamentaria, surgió la duda de si se podía considerar que el mantenimiento por parte del propietario de un determinado inmueble en situación permanente de desocupación podría ser considerado como un incumplimiento del deber de conservación. Finalmente, se derivó a la futura ley de vivienda este interesante debate.
} 


\section{$\underline{\text { Reforzamiento de la intervención administrativa en el mercado del suelo }}$}

Aunque esta materia requeriría de un análisis más exhaustivo, el tratamiento jurídico del legislador urbanístico no deja de entrever una evolución constante. Desde la incorporación de la institución de los Patrimonios Públicos del Suelo del legislador de 1956 hasta la configuración junto con esta de otras fórmulas jurídicas a favor de las administraciones públicas como las reservas de suelo y los derechos de tanteo y retracto en el Texto Refundido de $1992^{56}$.

No obstante no es ningún descubrimiento, antes lo hemos dejado apuntado también, que varios han sido los factores que, muchas veces combinados sus efectos, han mitigado - cuando no han anulado - la virtualidad de estas medidas. Nos referimos concretamente al problema de la financiación municipal y al sistema de valoraciones de suelo. Efectivamente, de nada vale añadir en la legislación medidas de intervención ingeniosas cuando las mismas no pueden ser operativas bien porque el sistema jurídico y el régimen de valoraciones de suelo protegen al propietario de suelo bien porque las arcas municipales no pueden hacer frente a esta inversión en suelo de recuperación en el largo plazo.

A ello hay que añadir la mala práctica municipal que, en vez de utilizar estos instrumentos para la búsqueda del equilibrio en el mercado del suelo, han utilizado estas instituciones en aras a obtener otros fines ajenos al objetivo prioritario de vivienda y, en segundo lugar, a otros fines de interés público que poco o nada tienen que ver con esa función reguladora del mercado del suelo. No podemos dejar de llamar la atención sobre la realidad en la mayoría de nuestros municipios de la implantación y funcionamiento práctico de la institución de los patrimonios públicos de suelo que, no pocas veces, no se ha traducido para esos ayuntamientos en años en la disposición pública de terreno alguno al haberse destinado sus recursos a otros fines.

Por ello el legislador urbanístico vasco, no siendo competente para corregir ninguno de los factores apuntados, hace un esfuerzo para reforzar las medidas públicas preexistentes exigiendo al mismo tiempo mayor responsabilidad a las administraciones públicas locales en el ejercicio de esas facultades, sobre todo en aras a la contribución a la regulación del mercado del suelo y resolución del problema de la vivienda. Esto es, se acompaña a la idea del reforzamiento de la intervención de lo local, la exigencia de destinar dichos esfuerzos a sus fines legítimos.

\section{Reforzamiento de medidas de intervención administrativa en materia urbanística}

Una de las primeras medidas que deberíamos destacar es la figura de la reparcelación forzosa - artículo 48 -. Así, se conceptúa la misma como aquella que es aprobada por la administración local sin consentimiento de la totalidad de la superficie de terrenos afectados. La regulación extensiva de esta institución se justifica desde el momento en que se tiene en cuenta que, en el marco de la propia reparcelación, se debe facilitar el acceso de todas las administraciones públicas a aquellas parcelas sobre las que se ha implantar los llamados "usos urbanísticos débiles" previamente definidos en el artículo 16 - esto es, vivienda protegida e implantación de actividades económicas de fomento e interés público -. De esa manera, el artículo 48 faculta a todas las administraciones públicas responsables de la implantación de dichos usos para forzar

\footnotetext{
${ }^{56}$ MAGUREGUI SALAS, Iñigo: "La intervención administrativa en el mercado del suelo. Una visión histórico - crítica.". Ponencia expuesta en las jornadas previas a la Asamblea Plenaria de la Asociación AVS. Donostia - San Sebastián. 2005.
} 
ante la propiedad del suelo la reparcelación de cara a facilitar la obtención de la titularidad pública de dichos terrenos. Más novedoso puede resultar el párrafo cuarto del citado artículo que para las entidades públicas no requiere la previa titularidad de terrenos para participar en la comunidad reparcelatoria ${ }^{57}$. Lo que se pretende con ello es facilitar el acceso de dichas administraciones a la titularidad dominical de los terrenos destinados por la ordenación a la implantación de usos urbanísticos protegidos por la ley. Todo ello sin necesidad de haber adquirido terrenos con anterioridad para poder tener acceso a dicha participación. Ciertamente, hay ciertos paralelismos entre esta regulación y la del agente urbanizador al que se le da preferencia de elección de cobro de la obra urbanizadora en forma de solares cuando los mismos sean destinados a vivienda protegida - artículo 150 -.

Otra de las instituciones jurídicas que ven extendida su regulación son las reservas de suelo sometidas a los derechos de tanteo y retracto. Frente a su objeto tradicional cual es la obtención pública de terrenos para, mediante su incorporación a la ordenación urbanística, regular el mercado de suelo y de vivienda, el legislador ha estimado que su virtualidad puede y debe ser extendida a otros objetivos. Así el artículo 119.2 extiende la figura de las reservas para la obtención pública de suelo no urbanizable de especial protección en aras a su mantenimiento o explotación adecuada a sus valores primarios. En esta misma línea, se debe señalar que el artículo 125 extiende la posibilidad de sujetar a tanteo y retracto a todos los bienes y derechos declarados fuera de ordenación así como aquellos bienes que deban ser comprendidos en actuaciones de rehabilitación, si así lo previeran los planeamientos respectivos.

Para finalizar esta primera parte, no se puede dejar de destacar la institución de la dotación residencial protegida - artículo 130 -. Esta institución se materializa en el derecho superficiante de las parcelas que albergan vivienda protegida y que hayan sido promovidas en el régimen del derecho de superficie, derecho superficiante a la que la ley otorga carácter dotacional si la ordenación estructural así lo establece en el contexto de la red de sistemas generales ${ }^{58}$. La reflexión que descansa bajo esta figura novedosa es que, en un contexto de agotamiento del suelo disponible en nuestros pueblos y ciudades, las futuras estrategias públicas de intervención administrativa en materia de suelo deberán radicarse sobre los terrenos hoy urbanizados que deberán ser objeto de reconversión el día de mañana. Consecuentemente, parece razonable que las administraciones públicas se reserven ciertas facultades dominicales sobre los suelos públicos sometiendo su explotación, por ejemplo, a límites temporales mediante la figura del derecho de superficie.

No obstante, la calificación permanente en el régimen público de protección de todas las viviendas protegidas, mandato establecido en la Disposición Adicional Octava en su párrafo séptimo, en cierta medida asegura también la permanente afectación de dichos suelos al interés público que justificó originalmente su promoción residencial. Y ello contribuye en gran medida a mitigar el debate antes enunciado.

Los controles legales del Patrimonio Municipal de Suelo

\footnotetext{
${ }^{57}$ El párrafo cuarto del artículo 48 de la Ley 2/2006 dicta lo siguiente: "Las entidades enumeradas (...) del número anterior podrán, a su elección, participar en la reparcelación aportando a favor de la comunidad reparcelatoria constituida una compensación económica a cuenta de los costes de la futura urbanización, al objeto de obtener participación en la edificabilidad urbanística."

${ }^{58}$ Ver artículo 54.2.f) de la Ley 2/2006.
} 
También el problema de la financiación municipal y la desproporción entre los recursos municipales y las crecientes demandas y exigencias ciudadanas de servicios públicos por parte de los Ayuntamientos ha contribuido en buena medida a desvirtuar los intereses perseguidos por la institución de los Patrimonios Municipales de Suelo - en adelante, PMS -. De esta forma, los Ayuntamientos han encontrado en el Urbanismo una fuente autónoma de financiación municipal que se han dirigido a financiar otros intereses ajenos a la regulación del mercado del suelo y de la vivienda. Por todo ello, la mayor autonomía municipal reconocida en la Ley 2/2006 en materia de Urbanismo se tiene que ver compensada con mayores exigencias del legislador en aras a recuperar, en la mayor medida de lo posible, el original sentido del instituto de los PMS.

Para ello lo primero que se exige a los Ayuntamientos es que se abandone la práctica de la monetarización de los derechos municipales a la edificabilidad urbanística. La monetarización provoca la desaparición del concepto de "suelo" dentro de los patrimonios municipales. Difícilmente se puede pretender regular el mercado de suelo desde las instituciones públicas si estas mismas se inhiben de sus responsabilidades mediante el abandono del papel protagonista en la intermediación de la compraventa de suelos y parcelas en sus respectivas localidades. Así, el artículo 27.4 de la Ley 2/2006 exige que la cesión de edificabilidad urbanística a favor de los Ayuntamientos se materialice en todo caso en parcela edificable añadiendo que si esa parcela tuviera uso residencial y no estuviera previsto por el planeamiento la construcción de vivienda pública - piénsese en municipios no obligados por tamaño por la Ley a reservar suelo para vivienda protegida - dicho suelo público deberá destinarse a vivienda pública ${ }^{59}$.

En esta misma orientación de mayor exigibilidad debemos destacar como novedades respecto a la precedente Ley vasca 20/1998 de Patrimonios Públicos de Suelo las siguientes:

a) Se prohíben las subastas de suelos municipales sustituyendo su sistema de enajenación por el de concurso o permuta - artículo 116 -.

b) Se extiende a más ayuntamientos la obligación de destinar al PMS parte de sus ingresos ordinarios. Anteriormente, se exigía sólo a los municipios de más de 7.000 habitantes y ahora quedan obligados todos los municipios de más de 3.000 habitantes, con carácter general - artículo 114.3 -.

c) Se liga más expresamente las cantidades consignadas en el presupuesto con los destinos legales del PMS puesto que se exige que en la memoria de dichos presupuestos se especifique qué cantidad y a qué concreto destino se prevé su destino evitando los cumplimientos genéricos y difusos de esta obligación de consignación presupuestaria - artículo 114.1 -.

Uno de los aspectos más significativos y debatidos entre el Gobierno Vasco y los Ayuntamientos sobre esta mayor exigibilidad hacia los Ayuntamientos en materia de PMS consistió en determinar la mayor o menor apertura de los destinos legales de los mismos. Tras

\footnotetext{
${ }^{59}$ Concretamente, el citado párrafo dispone literalmente lo siguiente: "La cesión regulada en este artículo se habrá de materializar en parcela edificable. Los municipios no obligados por esta ley a reservar suelo con destino a vivienda protegida y que no contemplen en el área, sector o, en su caso, unidad de ejecución de uso predominante residencial reserva alguna de suelo con este fin, deberán destinar las parcelas así obtenidas para vivienda de protección pública."
} 
un largo debate, la situación de partida y de llegada ha quedado configurada de la siguiente forma:

\begin{tabular}{|l|l|}
\hline Ley 2/2006 de Suelo y Urbanismo & Ley 20/1998 Patrimonio Público de Suelo \\
\hline Preferentemente, vivienda de protección & Preferentemente, vivienda de protección \\
\hline Adquisición de suelo de reservas y tanteos & No se prevé \\
\hline Adquisición de suelo actividades económicas & Adquisición de suelo actividades económicas \\
\hline Rehabilitación patrimonio histórico - cultural & Rehabilitación patrimonio histórico - cultural \\
\hline Equipamientos colectivos municipales & Equipamientos colectivos municipales \\
\hline Dotaciones públicas en zonas degradadas & Dotaciones públicas en cualquier ámbito \\
\hline No se prevé & Operaciones de rehabilitación y regeneración \\
\hline No se prevé & Conservación del medio físico natural \\
\hline
\end{tabular}

Como se observará, el legislador ha avanzado, aunque tímidamente, algunos aspectos que suponen vincular más estrechamente los destinos posibles de los PMS a sus objetivos primigenios cuales son la intermediación en el mercado de suelo y de la vivienda. Así, frente a la aparición de un nuevo destino como es la obtención de suelos delimitados en las reservas municipales y áreas de tanteo y retracto - directamente vinculado a la intervención administrativa en el mercado - se destaca la simultánea desaparición de destinos anteriormente posibles como la financiación de operaciones de regeneración urbanística o de conservación del medio físico - operaciones que nada o poco tienen que ver con el objetivo de dicha intermediación inmobiliaria - o las mayores limitaciones en otros posibles destinos financiación de dotaciones públicas que ahora quedarían necesariamente circunscritas a áreas degradadas-.

No obstante lo anterior, se debe seguir señalando que la mayor parte de los destinos posibles de los PMS, que acompañan al preferente de construcción de vivienda protegida, y señalados tanto en la legislación precedente como en la actual - estos son, la rehabilitación del patrimonio histórico, la construcción de equipamientos municipales y la financiación de dotaciones públicas - siendo intereses públicos dignos de atención, obedecen más a las propias necesidades de financiación municipal que a las exigencias de regulación del mercado de suelo y la vivienda. Ello explicaría que el propio artículo 111 de la Ley 2/2006 haya colocado, entre los objetivos del PMS, la finalidad de "facilitar el desarrollo territorial y urbanístico" - letra c - junto con la regulación del mercado de suelo y de la vivienda - letras a y b -. 


\section{La alteración del panorama competencial}

\section{Empoderamiento local}

Uno de los aspectos más controvertidos de la Ley 2/2006 de Suelo y Urbanismo ha sido la alteración del panorama competencial a favor de los Ayuntamientos. Tras la aprobación de esta legislación el mundo local verá fortalecido tanto sus competencias en materia de aprobación de planes urbanísticos, ejecución urbanística, facultades de intervención pública ante la propiedad del suelo y, más explícitamente, la regulación de algunos aspectos sectoriales, anteriormente vedados, como es la vivienda de protección pública.

Ciertamente, la necesidad de atender convenientemente los objetivos explicitados en los apartados anteriores pasa necesariamente por el "empoderamiento local" frente al resto de los agentes que han intervenido de diferentes formas en el mercado inmobiliario. Este empoderamiento se explicita de las siguientes formas:

- Empoderamiento frente al mercado inmobiliario y a los agentes privados. La configuración del Urbanismo como una función pública presupone, por poner solo unos ejemplos novedosos, la necesidad de reforzar los mecanismos de intervención en el mercado inmobiliario en manos de las Administraciones Públicas, la facultad de calificar suelos para usos protegidos por encima de la ley, la configuración de las actuaciones de urbanización como responsabilidad de las Administraciones Públicas y las facultades públicas de sustitución forzosa de los propietarios en las actuaciones edificatorias y rehabilitadoras.

- Empoderamiento frente al resto de Administraciones Públicas de ámbito supralocal. En este apartado deberíamos incluir la alteración del régimen de reparto competencial en materia de aprobación de planeamiento a favor de los Ayuntamientos y la novedosa configuración compartida de la responsabilidad en el señalamiento de figuras de protección pública de la vivienda. La búsqueda de flexibilidad en la ordenación urbanística busca la reducción de plazos entre la toma de una decisión pública y la puesta en práctica de la misma. Así, la atribución competencial, no exenta de controles de ámbito supralocal, de la aprobación definitiva de planeamiento urbanístico a favor de los Ayuntamientos supone una reducción de los plazos de tramitación de dichos planes. Del mismo modo, se consigue mayor implicación de los Ayuntamientos en la gestión y ejecución las decisiones de ordenación que ellos mismos han adoptado, facilitando por lo tanto la ejecutividad de las mismas. En otro orden de cosas, la participación ciudadana para ser real debe residenciar las últimas decisiones de planificación en los Ayuntamientos. El impulso de las políticas sectoriales en materia de vivienda y de obtención de suelo para actividades económica de fomento e interés público descansa en esta Ley, como ya ha quedado expuesto antes, en la técnica de la calificación urbanística. La decisión de la intensidad de las calificaciones de suelos para usos protegidos, dentro de los mínimos legales, presupone la conveniencia de otorgar competencia a los Ayuntamientos para la configuración no sólo de las ya citadas intensidades sino de las figuras de protección que se estimen más convenientes para atender las necesidades de su población. 


\section{La aprobación municipal de planeamiento urbanístico}

Llegados a este punto, conviene destacar que a través de las legislaciones de repartos competenciales entre el Gobierno Vasco y las Diputaciones Forales el mundo local fue progresivamente apartado de la competencia urbanística. Por otra parte, la proliferación de normativas sectoriales vinculantes para los planeamientos urbanísticos supuso la reducción del campo de acción de los propios Ayuntamientos en el diseño y planificación de sus pueblos y ciudades. A todo ello hay que sumar la confusión que existía sobre los límites de las escalas territoriales y de las escalas de ordenación locales en un contexto de complejidad políticoinstitucional y de escasez superficial del territorio a ordenar por tantos agentes de forma concurrente. Este caldo de cultivo contribuyó a que "los controles de oportunidad" por parte de las instituciones supralocales excedían en ocasiones el ámbito de la ordenación territorial y de la legalidad sectorial entrando, en algunas ocasiones, en consideraciones de oportunidad y de competencia, por tanto, estrictamente municipal.

Esta circunstancia junto con la necesidad de articular mayor flexibilidad a la tramitación de los documentos de planeamiento urbanístico municipal - aspecto ya comentado anteriormente decantó decisivamente al legislador hacia la opción "municipalista" en materia de aprobación de planes urbanísticos. Así, los ayuntamientos de más de 3.000 habitantes pueden tramitar y aprobar los planes de ordenación pormenorizada sin ningún tipo de control supramunicipal artículo 95-.

Por otra parte, los ayuntamientos de más de 7.000 habitantes tienen la competencia de aprobación definitiva de planes de ordenación estructural previo informe de las administraciones supralocales de carácter preceptivo y vinculante en materias como legalidad, ordenación territorial, cumplimiento de normativa sectorial y afectación de intereses supramunicipales - artículo 91-. Con esta regulación el legislador adapta la jurisprudencia del Tribunal Supremo ${ }^{60}$ que deslinda las facultades de control de las instituciones supramunicipales para poder ser dicha actividad tuitiva calificada de respetuosa con el principio de la autonomía municipal. Por lo tanto, queda vedado a las instituciones públicas supralocales el cuestionamiento en los planes urbanísticos de aspectos "de oportunidad", cuestiones que quedan reservadas al mundo municipal cuyo juicio siempre es prevalente, con la única excepción de si estas cuestiones afectan a otros intereses que exceden del ámbito local.

No obstante, el panorama no queda exactamente perfilado si nos circunscribimos al aspecto puramente competencial de aprobación de los planes urbanísticos. Así, es importante resaltar que a tenor de la ley las Diputaciones Forales, como instituciones competentes en materia de Agricultura, ven reforzada su capacidad de intervención pública para el control municipal del uso que se practica y autoriza en el suelo no urbanizable. Ello es especialmente importante en aspectos tan conflictivos como la proliferación del uso residencial en suelo no urbanizable bajo la excusa de ocupación de un caserío preexistente - artículo 30 -, de la preexistencia de un núcleo rural tradicional - artículo 29 - o la necesidad de construir una vivienda anexa a una explotación agropecuaria - artículo 31 -. También se deberán someter a autorización expresa de la Diputación Foral correspondiente cada uno de los proyectos previstos por el planeamiento territorial o urbanístico para el establecimiento en suelo no urbanizable de dotaciones, equipamientos y actividades declarados de interés público - artículo 28.5 -.

\footnotetext{
${ }^{60}$ En este sentido, consultar la STS de 18 de Mayo de 1992 (RA 4219)
} 
Con carácter adicional, los controles de las entidades supramunicipales a través de la Comisión de Ordenación del Territorio del País Vasco se aseguran por la Ley para todos los planes y modificaciones de ordenación estructural - que afectan al suelo no urbanizable -, los estudios de impacto ambiental de los planes urbanísticos - artículo 91 - así como el planeamiento especial de protección y conservación de elementos naturales - artículo 72 -.

Por ello sería más exacto circunscribir la desaparición de controles de oportunidad de las entidades supramunicipales en lo que tiene por objeto tanto el suelo urbano y el urbanizable esto es, en lo que refiere a las decisiones relativas a la expansión, al desarrollo y a los crecimientos urbanísticos -. Por el contrario, en aquellos aspectos referentes a la sostenibilidad y al mantenimiento y preservación del medio ambiente, los controles se mantienen en las entidades públicas supramunicipales por entender el legislador que la sostenibilidad y el medio ambiente debe ser considerado y ordenado desde una escala superior a la local.

\section{El impulso de la participación ciudadana}

El mayor contrapeso en cuestiones de oportunidad política de la facultad de ordenación urbanística municipal lo constituye el espectacular avance que en la regulación legal experimenta la participación ciudadana. Sólo si se parte de la premisa de que la última decisión sobre determinados aspectos urbanísticos radica en la propia sede municipal los mecanismos de participación ciudadana articulados desde el propio ayuntamiento resultan creíbles. De hecho, el artículo 109 del texto legal vincula la competencia de aprobación definitiva de planes generales a la existencia de un Consejo Asesor de Planeamiento que deberá emitir informes de carácter preceptivo pero no vinculante en la tramitación bien de la primera formulación, bien de la revisión bien de cualquier modificación de dichos planes generales.

Por otra parte, la apuesta que la ley hace a favor del fomento de la participación ciudadana en la ordenación urbanística parte de la convicción de que el diseño de la ciudad, como parte de la función pública urbanística, afecta al interés público e incide directamente en el bienestar y en la calidad de vida de todos los ciudadanos. Ello obedece a los principios legales ya comentados tanto de concertación social - artículo 6.2 - como de participación ciudadana especialmente, artículo 8.1 -. Por encima de intereses particulares, la decisión sobre la estrategia de ocupación del suelo, la decisión sobre la concreta localización de las infraestructuras, de las dotaciones y equipamientos públicos y las decisiones sobre la presencia de vivienda protegida, por poner sólo unos ejemplos sencillos, son cuestiones públicas que deben estar abiertas a la participación ciudadana.

Por ello el artículo 108 exige que el acuerdo municipal de inicio de formulación de modificación o revisión de cualquier instrumento de planeamiento de ordenación estructural - plan general, plan de compatibilización, plan de sectorización - venga acompañado necesariamente de un programa de participación ciudadana en el que se diseñen las estrategias para posibilitar y fomentar el conocimiento de sus contenidos a entidades asociativas y a los ciudadanos y la participación de estos en el proceso de elaboración y decisión. Entre los instrumentos de participación ciudadana que expresamente se prevén, destacamos los siguientes:

a) Sesiones abiertas al público explicativas del contenido del Avance y de las estrategias de construcción de la ciudad así como de todas las alternativas presentadas en el expediente. 
b) Consultas populares, con arreglo a la legislación de régimen local, en caso de graves controversias ciudadanas sobre alguno de los aspectos incluidos en el planeamiento.

c) Material divulgativo que deberá ser preparado junto con los documentos legalmente exigidos para los instrumentos urbanísticos, al objeto de facilitar su difusión y su comprensión.

Estas propuestas legales tienen directo enlace con las medidas recomendadas por la Agenda Local 21, estrategia de desarrollo sostenible asumida por una gran parte de municipios de la Comunidad Autónoma, por lo que estas previsiones legales ya venían siendo aplicadas con diferente intensidad por algunos municipios.

Enlazado con lo anterior, citar que para el correcto funcionamiento de las previsiones legales para el fomento de la participación ciudadana resulta imprescindible contar con un esquema de información pública urbanística. Resulta imprescindible en este sentido destacar el artículo 9 del texto legal que consagra el sometimiento de toda la documentación de información urbanística al principio de publicidad. Así mismo, el artículo 107 establece la obligación municipal de actualización de la documentación de planeamiento a los efectos de hacer posible y operativa dicha información ciudadana de los contenidos de la ordenación urbanística.

Finalmente, resaltar que en todo el cuerpo legal se consolida el esquema procesal tradicional de exposición al público para información pública y para la presentación de alegaciones por parte de los ciudadanos. En este sentido, destacar simplemente que en la Disposición Adicional Séptima se da carta de naturaleza a la práctica de la firma de convenios urbanísticos entre las administraciones públicas y particulares a los efectos de someter los mismos a información pública y, por lo tanto, control ciudadano. 


\section{ANEXO ${ }^{61}$ \\ RELACIONES ENTRE EL PROYECTO DE LEY DE SUELO DEL ESTADO Y LA LEY VASCA 2/2006 DE SUELO Y URBANISMO}

\section{INTRODUCCIÓN}

La Ley vasca 2/2006 de Suelo y Urbanismo (en adelante, LvSU) aprobada en el Parlamento vasco el día 30 de Junio de 2006 se tramitó al mismo tiempo que el Anteproyecto de Ley de Suelo del Estado - que se aprobó como Proyecto de Ley sólo días después-. De esta forma, se puede observar que ambas normas guardan en determinados aspectos una estrecha relación y sus respectivas regulaciones coordinan en el ejercicio normativo de sus respectivos ámbitos de competencia.

Tal es así, que podemos afirmar que la LvSU está a día de hoy plenamente adaptada a los contenidos y mandatos del Proyecto de Ley de Suelo estatal (en adelante, PLS). Esto se afirma sin perjuicio de la conveniencia de realizar en una futura modificación puntual legislativa determinadas adaptaciones que mejoren el texto actual a la luz de las nuevas posibilidades otorgadas por la legislación estatal (por ejemplo, incrementar la participación de la comunidad en las plusvalías urbanísticas del $10 \%$ al $15 \%$, etc.)

A continuación, haremos un breve repaso de los aspectos y puntos interesantes de conexión entre el PLS y la LvSU.

\section{EL URBANISMO Y SU RELACIÓN CON LOS DERECHOS CIUDADANOS}

Debemos saludar con satisfacción el enfoque novedoso que incorpora el PLS. Efectivamente, este proyecto de ley se separa de la asimilación simplista de la Ley 6/1998 en el que se limita a regular los derechos y deberes urbanísticos de la propiedad del suelo. Así, los principios de sostenibilidad y de respeto al interés general son dos principios que, como derechos ciudadanos que son, deben ser respetados por la actividad urbanística (artículo 2.1 del PLS). Ello guarda íntima relación con la definición del artículo 3.1 del PLS que define la potestad de la ordenación territorial y urbanística como funciones públicas.

En la LvSU se sigue un esquema parecido al propuesto en el PLS. Así, el artículo 2 habla expresamente del Urbanismo como una función pública que se ejerce guiada por los principios generales que se citan en los artículos 3 y siguientes LVSU, principios entre los que figura el sometimiento de la ordenación al interés público y sujeción tanto a los principios como a los límites exigidos por el desarrollo sostenible. Así mismo, se regulan los principios de la

\footnotetext{
${ }^{61}$ Esta ponencia fue objeto de intervención en las Jornadas sobre Urbanismo organizadas por la Asociación Española de Promotores de Vivienda y Suelo (Sevilla, 30 y 31 de Enero de 2007)
} 
información pública y de la participación ciudadana - también ambos citados entre los deberes de las Administraciones Públicas en el artículo 11 PLS -.

En estos tiempos de "convulsión urbanística" echamos de menos en el PLS una mayor profundización en la regulación del sometimiento de la ordenación al interés general o público vinculando la validez de las determinaciones de ordenación territorial o urbanística a la previa acreditación del interés público que las justifica (artículo 4 LvSU).

\section{EL URBANISMO Y SU RELACIÓN CON LOS DERECHOS DE PROPIEDAD}

También compartimos plenamente desde el País Vasco el importante cambio de orientación del PLS respecto al entendimiento y alcance que se otorga al derecho de la propiedad del suelo en la actual Ley 6/1998. Efectivamente, el mandato del uso del suelo conforme al interés general junto con la interdicción constitucional de la especulación exige un radical cambio de dirección sobre el tratamiento de la patrimonialización de los derechos no ejecutados contenidos en las previsiones en los planes urbanísticos. No podemos dejar de citar el importantísimo cambio de dirección que en este sentido supone el artículo 7 del PLS:

"Artículo 7. Régimen urbanístico del derecho de propiedad del suelo.

1. El régimen urbanístico de la propiedad del suelo es estatutario y resulta de su vinculación a concretos destinos, en los términos dispuestos por la legislación sobre ordenación territorial y urbanística.

2. La previsión de edificabilidad por la ordenación territorial y urbanística, por sí misma, no la integra en el contenido del derecho de propiedad del suelo. La patrimonialización de la edificabilidad se produce únicamente con su realización efectiva y está condicionada en todo caso al cumplimiento de los deberes y el levantamiento de las cargas propias del régimen que corresponda, en los términos dispuestos por la legislación sobre ordenación territorial y urbanística."

Por cuestiones competenciales está vedado al legislador urbanístico regular lo relativo al derecho a la propiedad. Por ello, en los artículos 18 y siguientes de la LvSU se limitan a enunciar cuales son facultades y deberes de la propiedad del suelo conforme a las vinculaciones y limitaciones establecidas en la ordenación urbanística - tal como habilita el artículo 7.2 in fine del PLS -. Posteriormente, la LvSU pasa a afirmar el carácter estatutario del derecho de propiedad del suelo respecto a dichas facultades y deberes. El homólogo más próximo por tanto de la legislación urbanística vasca a este artículo 7 lo encontramos en el artículo 24.2 LvSU que dispone:

"2. El cumplimiento de los deberes [urbanísticos] enunciados es condición previa en cada caso del legítimo ejercicio de las facultades previstas en este título."

Por lo tanto, tanto en la legislación básica estatal como en la urbanística vasca no se pueden obtener derechos sin cumplir los deberes inherentes a estos mismos derechos. 
Una de las previsiones que más polémica ha suscitado en la redacción actual es la apertura del ejercicio del derecho a urbanizar a la iniciativa de libre empresa quitando la exclusividad de dicho derecho al propietario privado del suelo. Se recoge expresamente - y no excepcionalmente como se hacía hasta ahora - la posibilidad de abrir la facultad de urbanizar a un tercero ajeno a la propiedad original del suelo (el agente urbanizador).

Ello no supone ninguna novedad respecto a la legislación urbanística vasca que recoge expresamente el sistema de agente urbanizador (artículos 166 y ss), no sólo como una posibilidad más de actuación - junto con el sistema de concertación con propietarios - sino también en coherencia con el carácter de obra pública que la Ley vasca otorga a las obras de urbanización, en función de lo dispuesto en su artículo 197 LvSU. Así, también se comprende la obligación - cualquiera que sea el sistema de actuación elegido - de someter la selección de contratistas para la ejecución material de las obras de urbanización a los principios de contratación pública (artículo 172 LvSU).

El artículo 9 del PLS y su correlativo artículo 31, que desarrollan el concepto de los deberes de la propiedad del suelo desde su sometimiento al principio de la función social de la propiedad en relación al suelo y a la edificación, limitan aparentemente - estimo que no de forma muy justificada - su virtualidad a los deberes de edificación y de conservación de lo edificado. En todo caso, el artículo 31 PLS abre la vía expropiatoria para los suelos no edificados o edificaciones no rehabilitadas en plazo (algo que ya venía siendo tradicional en la legislación urbanística, concretamente en la LvSU artículos 189 y 203) amen de fijar otras técnicas como la venta o sustitución forzosa (también establecidas en los artículos 190 y siguientes de la LVSU, aunque las mismas podrán ser complementadas con lo que disponga la legislación básica una vez aprobada).

Para terminar este apartado no podemos dejar de citar el artículo 16.3 del PLS, relativo a los convenios urbanísticos y que, tal como aparece redactado, reza lo siguiente:

"3. Los convenios o negocios jurídicos que el promotor de la actuación celebre con la Administración correspondiente, no podrán establecer obligaciones o prestaciones adicionales ni más gravosas que las que procedan legalmente de acuerdo con lo dispuesto en este artículo, en perjuicio de los propietarios afectados. La cláusula que contravenga estas reglas será nula de pleno Derecho"

La Disposición Adicional Séptima de LvSU que regula los convenios urbanísticos viene ya a decir algo idéntico pero expresado de forma más genérica cuando declara nulas de pleno derecho las estipulaciones de los convenios urbanísticos que contravengan o defrauden normas imperativas legales o reglamentarias, incluidas las contenidas en el planeamiento territorial o urbanístico.

No obstante, hay que advertir que de la lectura del apartado se pueden deducir infinidad de problemas, tal como aparece redactado. Si bien podríamos estar de acuerdo que los acuerdos extra legem entre el promotor de una actuación y la Administración no pueden ser repercutidos a terceros propietarios, no es menos cierto que el tenor literal del párrafo parece reconducir las obligaciones imputables a la propiedad sólo a las relacionadas en el artículo 16 PLS. Ello puede ser fuente de importantes conflictos cuando son varias las Comunidades Autónomas, 
que en el ejercicio su competencia en materia de Urbanismo, han extendido dichas obligaciones a cargo de la propiedad del suelo a otras diferentes (así por ejemplo, el supuesto de la descontaminación e inertización de suelos contaminados en el artículo 147.3 LvSU). Esperemos que en trámite de enmiendas el tenor literal de este párrafo quede corregido.

\section{DEBERES DE LAS ADMINISTRACIONES PÚBLICAS}

Los artículos 10 y siguientes establecen los deberes de las Administraciones Públicas en relación con la actividad urbanística y que se corresponden con los derechos de la ciudadanía en relación con dicha actividad urbanística.

En relación con los deberes de información pública y de participación ciudadana, principios también recogidos como tal en la LvSU - artículos 8 y 9 -, esta última va bastante más allá en materia de participación ciudadana, muy especialmente en relación con la actividad de planificación urbanística municipal. Así por ejemplo, el artículo 108 LvSU obliga a cualquier revisión o modificación de planeamiento de ordenación estructural - entendiendo por tales bien los documentos de Plan General, Plan de Sectorización, Plan de Compatibilización - de acompañar un programa específico de participación ciudadana para difundir sus contenidos. Así mismo, en la LVSU los municipios de entidad poblacional superior a 7.000 habitantes tienen la obligación de constituir un "Consejo Asesor de Planeamiento" - de composición mixta política y ciudadana - para su informe en todo expediente de alteración del Plan General. Dicho informe es preceptivo (determinante) pero no vinculante.

La incidencia de la futura entrada en vigor del PLS sí tendrá impacto en las legislaciones urbanísticas en lo que hace referencia a la regulación novedosa en materia de evaluación y seguimiento de la sostenibilidad en el desarrollo urbano - artículo 15 PLS -, aspecto de obligado cumplimiento por la transposición de las Directivas Europeas en la Ley 9/2006. En ese sentido, la introducción como obligatoria de la evacuación de los informes de Evaluación Conjunta de Impacto Ambiental en la tramitación de planes urbanísticos, prevista en las respectivas legislaciones urbanísticas, se me antojan no suficientes al efecto de dar pleno cumplimiento en lo exigido en este artículo.

Mucha mayor importancia tiene, en nuestra opinión, el importante paso dado por la legislación básica en este PLS en materia de vivienda protegida. Lo primero que hay señalar es la inexplicable ausencia del concepto de "función social de la propiedad" en la Ley 6/1998. Y parecería lógico desde el mandato constitucional del artículo 47 CE que se hubiera regulado el sometimiento de la propiedad del suelo a los principios reguladores del interés general, señalando al mismo tiempo las consecuencias de dicho sometimiento.

Frente al silencio ¿cómplice? de la Ley 6/1998, el PLS termina su artículo 2 con una frase que me voy a permitir resaltar por suponer un cambio drástico de orientación respecto a la actualmente vigente Ley 6/1998. Así:

"El suelo vinculado a un uso residencial por la ordenación territorial y urbanística está al servicio de la efectividad del derecho a disfrutar de una vivienda digna y adecuada, en los términos que disponga la legislación en la materia." 
Esta previsión posteriormente da pie al legislador estatal para que en el artículo 10.b) PLS se establezca la obligación a las legislaciones urbanísticas de fijar, al menos, un porcentaje obligatorio de reserva de suelo para vivienda protegida.

La legislación vasca - ya en 1994 - fue la primera Comunidad Autónoma en todo el Estado que estableció legalmente la obligatoriedad de reserva de suelo para vivienda protegida. No en vano en la actualización de dicha reserva en la LvSU se establecen reservas obligatorias de edificabilidad del $75 \%$ - urbanizable - y del $40 \%$ - suelo urbano - para vivienda protegida en ámbitos residenciales de municipios de más de 3.000 habitantes. Esta previsión legal, avalada ahora por la legislación básica estatal, ha permitido a la CAPV alcanzar una cuota de mercado del $30 \%$ de vivienda protegida. Por ello, entendemos no sólo que es una medida correcta sino que además también necesaria.

Aunque quizás haya pasado más desapercibido entendemos así mismo un gran avance el hecho que, a petición de las Comunidades Autónomas Navarra y Vasca, se haya introducido en el apartado 2.a) del artículo 18 la obligación de indicar expresamente en las escrituras públicas de transmisión la condición de suelo destinado a vivienda protegida, garantizando de este modo su acceso a Registro de la Propiedad, previsión tan oportuna como necesaria. Decimos que es oportuna por la contribución a la transparencia y a la seguridad del tráfico jurídico que esta mención aporta. Decimos que es necesaria porque algunas Comunidades Autónomas, como es el caso del País Vasco, en el proyecto de ley de vivienda estamos considerando introducir con carácter general un precio máximo en las transmisiones onerosas de suelo urbanizado para vivienda protegida coincidente con el valor máximo de repercusión establecido en la normativa protectora. Así mismo, e íntimamente conectado con lo anterior, estamos considerando someter la transmisión de solares y parcelas calificadas para vivienda protegida al derecho de tanteo y retracto por parte del Gobierno Vasco.

\section{PATRIMONIOS PÚBLICOS DE SUELO. UN AVANCE NECESARIO}

En relación con la regulación propuesta para los Patrimonios Públicos de Suelo debemos constatar varios aspectos, que nos parecen un gran acierto. Devolver a las legislaciones urbanísticas de las Comunidades Autónomas la posibilidad de fijar con carácter general el porcentaje de participación de la comunidad en las plusvalías urbanísticas hasta un máximo de un $15 \%$ de la edificabilidad libre de cargas de urbanización es una medida con la que estamos plenamente de acuerdo (artículo 16.1.b)

Ello se afirma no por un ánimo "recaudatorio" de las Administraciones Públicas sino porque el mismo precepto ya se encarga de vincular preceptivamente dichos ingresos a atender las finalidades de los Patrimonios Públicos de Suelo. Así parece que quedará expresamente redactado, según el texto aprobado en la ponencia.

Pero mucho más importante, y con gran relevancia en la política de vivienda, tiene el apartado siguiente que reza lo siguiente: 
"La legislación sobre ordenación territorial y urbanística podrá determinar los casos y condiciones en que quepa sustituir la entrega del suelo por otras formas de cumplimiento del deber, excepto cuando pueda cumplirse con suelo destinado a vivienda sometida a algún régimen de protección pública en virtud de la reserva a que se refiere la letra b) del artículo 10."

Este precepto reafirma una obligación ya establecida en el artículo 27.4 LvSU que prohíbe con carácter general la monetarización de la edificabilidad obtenida en calidad de participación de la comunidad en las plusvalías urbanísticas.

Esto también venía siendo tradicional en la práctica urbanística municipal y que se ha dado en conocer en la tramitación del PLS como el "sistema vasco". Piénsese que en el País Vasco las reservas obligatorias para vivienda protegida tienen ya más de diez años. Este sistema consiste entonces, básicamente descrito, en utilizar los coeficientes de ponderación de uso para hacer coincidir los derechos municipales - 10\% ó $15 \%$ - con la totalidad o la mayor parte de las edificabilidades urbanísticas residenciales protegidas - urbanizadas o sin urbanizar, según sea el caso - de forma que el único promotor de vivienda protegida o es el propio Ayuntamiento o sus sociedades públicas participadas. Ello supone que desde las Administraciones Públicas se garantiza la oferta de vivienda protegida en plazo porque la misma es controlada por parte del Ayuntamiento (ejemplos de los desarrollos de BILBAO, DONOSTI y VITORIA-GASTEIZ).

Nos congratulamos que esta "buena práctica" ahora se adopte como obligatoria para todas las Comunidades Autónomas - y para la que creemos que el Estado tiene plena competencia -. Frente a la regulación tradicional de los Patrimonios Públicos de Suelo por parte de la legislación básica estatal - leyes LS1956, TRLS1976 y TRLRSU1992 - con el ánimo de regular el mercado del suelo y de la vivienda, la verdadera efectividad de esta institución jurídica la estamos conociendo de la mano de la combinación y vinculación de las reservas obligatorias de suelo para vivienda protegida y de los derechos urbanísticos municipales.

Así mismo, compartimos plenamente también la corrección de los supuestos de reversión del artículo 29.1.b) PLS que impide la reversión en los supuestos de expropiación para Patrimonios Públicos de Suelo. Con la legislación actual, dicha práctica se imposibilitaba en la práctica al exigir un proceso de revisión del planeamiento para la incorporación de dichos suelos a su desarrollo urbanístico, lo que convertía dicha expropiación en antieconómica.

Finalmente hay que llamar la atención sobre la regulación del derecho de superficie en relación con la política de vivienda protegida. En nuestra opinión, esta herramienta no ha sido todavía suficientemente considerada. En el País Vasco, forzados seguramente por la escasez de superficie apta para urbanizar en nuestro territorio, tanto desde el Gobierno Vasco como algún Ayuntamiento, aunque esto es más excepcional, hemos tomado la decisión de promover la vivienda protegida que no se destina al régimen de alquiler sólo en el régimen propio de derecho de superficie. Incluso la LvSU, a través de la figura de la dotación residencial protegida, permite dar a la superficie rasante (derecho superficiante) de las parcelas para vivienda protegida - esto es, una vez excluido su contenido económico que se materializará en el vuelo - el carácter dotacional. Por tanto, será dicho derecho superficiante objeto de reserva o bien de cesión obligatoria y gratuita con destino a Patrimonio Público de Suelo, según corresponda, a la Administración con el resultado que toda la vivienda protegida de un 
municipio se promueva en el régimen propio del derecho de superficie, si así lo estima el Ayuntamiento correspondiente.

Debemos avanzar en el concepto del Patrimonio Público de Suelo no sólo como una institución de presente, para favorecer desde lo público el equilibrio del mercado de suelo y vivienda actual, sino como una herramienta de intervención de futuro manteniendo desde lo público derechos suficientes sobre el territorio para asegurar la solidaridad intergeneracional también en materia de vivienda o regeneración urbana. Especialmente relevante resulta esta reflexión en aquellos territorios o ámbitos urbanos donde el suelo razonablemente apto para urbanizar está siendo agotado.

\section{SISTEMA DE VALORACIONES. CAMBIO DE RUMBO}

A pesar de lo expuesto, el mayor cambio que incorpora el PLS es la alteración drástica del sistema de valoraciones de suelo rompiendo, acertadamente en nuestra opinión, una tradición de más de 50 años. Y decimos que es una posición acertada porque por primera vez desde la Constitución de 1978 se huye de un sistema de valoración de suelo especulativo, en el sentido que incorpora plusvalías que no se han materializado / ejecutado en la práctica.

A raíz de la STC 61/1997, que como ya es conocido separó drásticamente la competencia de regulación en materia de urbanismo (CCAA) y la competencia de regulación de la propiedad del suelo (Estado), se presentó al legislador estatal la oportunidad de desvincular ambos conceptos de forma que el régimen de los derechos y deberes de la propiedad del suelo no se hicieran depender de la clasificación urbanística. Lejos de adoptar esta medida, el legislador estatal de 1998 optó, por el contrario, por irrogarse la competencia de clasificación urbanística asociando a la misma el estatuto del derecho de propiedad del suelo, algo que fue declarado acorde con la Constitución en la STC de 2001. Esa decisión del legislador estatal de 1998 en el sentido de vincular los conceptos de propiedad y de clasificación urbanística del suelo ha generado no pocos problemas para la adecuación a su modelo territorial que incorporan las legislaciones urbanísticas de las Comunidades Autónomas (por ejemplo, la confusa STC de Febrero de 2002 contra la Ley vasca 11/1998).

Por poner un ejemplo cercano, desde la CAPV nos hemos visto obligadas las Administraciones Públicas a violar el precepto constitucional que obliga a la participación de la comunidad en las plusvalías generadas por la acción urbanística cuando dichas plusvalías existen pero las mismas se materializan en suelo urbano consolidado por la urbanización. Esto es, en otras palabras, la patrimonialización privada y sin condiciones - ni de cesión del 10\% ni de cesión de dotaciones públicas - de las plusvalías urbanísticas generadas por "levante de edificios" o por cambio de usos en edificaciones o solares preexistentes. Ello tiene un enorme impacto económico en una Comunidad Autónoma donde desde hace unos años venimos haciendo un esfuerzo por regenerar nuestros tejidos urbanos intentando preservar el suelo natural de los procesos de expansión urbanística amen de suponer una evidente quiebra del principio de equidistribución y, lo que es más importante, del más mínimo principio de justicia social.

Evidentemente, la LvSU ha retomado esta problemática asumiendo la necesidad de compensar el déficit dotacional que resulta generado por este incremento de edificabilidad, aun sin ello 
suponer reforma de la "consolidación de la urbanización", a través del concepto de "consolidación por la edificabilidad". Así, la ley vasca asume, en base a la regulación de su modelo urbanístico propio, que todo incremento de edificabilidad urbanística va acompañado del deber de cesión del suelo dotacional correspondiente a ese incremento - o bien la indemnización sustitutoria cuando no sea físicamente posible - y además del deber de cesión del $10 \%$ aplicable a dicho incremento. Estos deberes se articulan bajo la figura de las actuaciones de dotación (artículo 137 LvSU) y que son una "tercera vía" entre las actuaciones aisladas e integradas.

Celebramos como una gran noticia el hecho de que el legislador estatal refiera la regulación del derecho de propiedad y, consecuentemente el sistema de valoración del mismo, a la situación BASICA y REAL del suelo y no a su clasificación urbanística. Ello encierra dos grandes ventajas. 1) La plena libertad del legislador autonómico para configurar la clasificación urbanística del mismo conforme a su modelo, como ya se ha explicado. 2) Evitar la incorporación de expectativas en las valoraciones de suelo en los justiprecios expropiatorios.

Tenemos, no obstante, que ser todos conscientes del importante e innovador paso que se propone en el PLS. Y todo lo innovador tiene la necesidad de venir acompañado de una absoluta y meridiana claridad para evitar "agujeros" o interpretaciones sesgadas de sus contenidos. Por ello, ya hemos manifestado desde la CAPV nuestro parecer al Ministerio de Vivienda - y hemos encontrado receptividad a nuestras propuestas -. En nuestra opinión, se deben corregir en sede parlamentaria algunos aspectos del sistema de valoraciones por mayor claridad. A saber,

a) La mejora en la redacción técnica del concepto de "suelo urbanizado" (artículo 12.3)

b) La posibilidad de corregir y sin ningún límite legal al alza el valor del suelo rural en determinadas circunstancias, situaciones que encierran conceptos jurídicos indeterminados o indeterminables - por ejemplo, parajes de demanda social intensa -.

c) Las confusas redacciones de los artículos 23.1.c) y 24.2 y que habría que aclararlas.

En lo que refiere a las relaciones de este nuevo sistema valorativo del PLS con la legislación urbanística vasca, habría que destacar algunos aspectos. Lo primero a destacar es que lo que primaría en este nuevo sistema para la valoración es, como ya se ha dicho, la situación real del bien objeto de valoración. Por ello, el momento de incorporación de la plusvalía urbanística al suelo es progresivo a su situación real de transformación. De este modo, adquiere especial relevancia marcar desde la legislación urbanística sobre todo el paso de un suelo de la situación básica inicial de rural a urbanizado, siendo prácticamente irrelevante a efectos valorativos el momento de la "reclasificación".

En la LvSU (artículos 152 y siguientes), las actuaciones urbanizadoras aparecen iniciadas a través de los llamados "Programas de Actuación Urbanizadora" exigibles en todas las actuaciones integradas - tanto en suelo urbano como en suelo urbanizable -. Estos Programas tienen la virtualidad de marcar unos deberes de urbanización, fijar el sistema de actuación y requieren, antes de su aprobación, el aval de la iniciativa privada del cumplimiento de los mismos en un determinado plazo. Por lo tanto, a partir de la entrada en vigor del PLS, los 
Programas de Actuación Urbanizadora extenderán su virtualidad también a señalar el "cronograma valorativo" de los suelos urbanizables.

Ni que decir tiene que una carga elevada de construcción de vivienda protegida en suelo urbanizable (mínimo del $75 \%$ de la edificabilidad residencial en la LvSU, aunque transitoriamente durante 2 años pueden funcionar con el 65\%) sólo puede ser activada desde las Administraciones Públicas mediante la amenaza expropiatoria una vez vencidos los plazos para su desarrollo. En ese sentido, la regulación de la Disposición Transitoria Tercera queremos suponer que tendrá la virtualidad de movilizar bastante suelo urbanizable sectorizado en el País Vasco con reservas altas de vivienda protegida. En este sentido, la expropiación con liberación pactada de bienes y derechos puede dar unos excelentes resultados como es el caso de la sociedad ENSANCHE XXI en Vitoria-Gasteiz.

En lo que refiere al suelo urbano sometido a operaciones de regeneración urbana. En el País Vasco se da el supuesto de sacar una industria o complejo industrial del tejido urbano residencial o bien se trata de operaciones de eliminación de infravivienda. El nuevo sistema valorativo permitirá facilitar dichas operaciones sin consideración de los usos urbanísticos futuros atribuidos por la ordenación (artículo 23.3). Ello complementado con la garantía del derecho de realojo de ocupantes legales de vivienda (Disposición Transitoria $4^{\text {a }}$ TRLSU, artículo 16 PLS y Disposición Adicional Segunda de LvSU) o con el procedimiento de reinstalación de actividades (Disposición Adicional Segunda LVSU) permitirá las operaciones públicas de regeneración socio-urbanística en las zonas degradadas de nuestros barrios y ciudades conjugando la racionalidad económica de las Administraciones Públicas y la justicia social. 
